\title{
Kindia (Pavetteae, Rubiaceae), a new cliff-dwelling genus with chemically profiled colleter exudate from Mt Gangan, Republic of Guinea
}

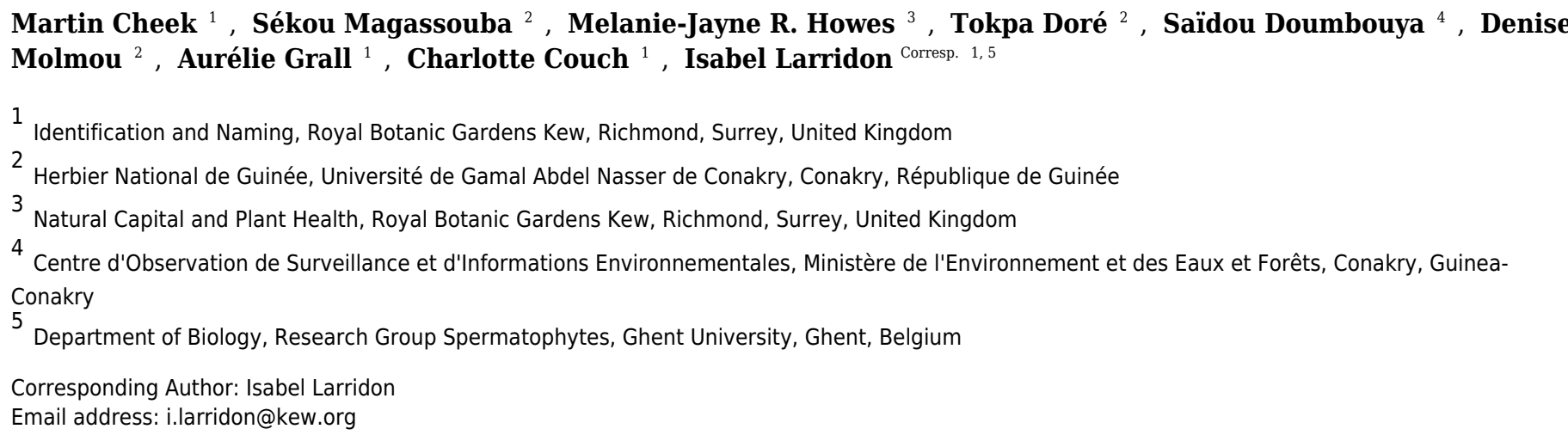

A new genus Kindia (Pavetteae, Rubiaceae) is described with a single species, $K$. gangan, based on collections made in 2016 during botanical exploration of Mt Gangan, Kindia, Republic of Guinea in West Africa. The Mt Gangan area is known for its many endemic species including the only native non-neotropical Bromeliaceae Pitcairnia feliciana. Kindia is the fourth endemic vascular plant genus to be described from Guinea. Based on chloroplast sequence data, the genus is part of Clade II of tribe Pavetteae. In this clade, it is sister to Leptactina sensu lato (including Coleactina and Dictyandra). Kindia gangan is distinguished from Leptactina s.l. by the combination of the following characters: its epilithic habit; several-flowered axillary inflorescences; distinct calyx tube as long as the lobes; a infundibular-campanulate corolla tube with narrow proximal section widening abruptly to the broad distal section; presence of a dense hair band near base of the corolla tube; anthers and style deeply included, reaching about mid-height of the corolla tube; anthers lacking connective appendages and with sub-basal insertion; pollen type 1; pollen presenter (style head) winged and glabrous (smooth and usually hairy in Leptactina); orange colleters producing a vivid red exudate, which encircle the hypanthium, and occur inside the calyx and stipules. Kindia is a subshrub that appears restricted to bare, vertical rock faces of sandstone. Fruit dispersal and pollination by bats is postulated. It is here assessed as Endangered EN D1 using the 2012 IUCN standard. High resolution LC-MS/MS analysis revealed over 40 triterpenoid compounds in the colleter exudate, including those assigned to the cycloartane class. Triterpenoids are of interest for their diverse chemical structures, varied biological activities, and potential therapeutic value. 
1 Kindia (Pavetteae, Rubiaceae), a new cliff-dwelling genus with chemically profiled colleter

2 exudate from Mt Gangan, Republic of Guinea

3

4 Martin Cheek $^{1}$, Sékou Magassouba ${ }^{2}$, Melanie-Jayne R. Howes ${ }^{3}$, Tokpa Doré ${ }^{2}$, Saïdou

5 Doumbouya $^{4}$, Denise Molmou ${ }^{2}$, Aurélie Grall ${ }^{1}$, Charlotte Couch ${ }^{1}$, Isabel Larridon ${ }^{1,5}$

6

$7{ }^{1}$ Identification and Naming, Royal Botanic Gardens Kew, Richmond, Surrey, United Kingdom

$8 \quad{ }^{2}$ Herbier National de Guinée, Université de Gamal Abdel Nasser de Conakry, République de

9 Guinée

$10{ }^{3}$ Natural Capital and Plant Health, Royal Botanic Gardens Kew, Richmond, Surrey, United

11 Kingdom

$12{ }^{4}$ Centre d'Observation de Surveillance et d'Informations Environnementales, Ministère de

13 l'Environnement et des Eaux et Forêts, République de Guinée

$14{ }^{5}$ Department of Biology, Research Group Spermatophytes, Ghent University, Ghent, Belgium

15

16 Corresponding author

17 Isabel Larridon,

18 i.larridon@kew.org 


\section{ABSTRACT}

21 A new genus Kindia (Pavetteae, Rubiaceae) is described with a single species, K. gangan, based

22 on collections made in 2016 during botanical exploration of Mt Gangan, Kindia, Republic of

23 Guinea in West Africa. The Mt Gangan area is known for its many endemic species including

24 the only native non-neotropical Bromeliaceae Pitcairnia feliciana. Kindia is the fourth endemic

25 vascular plant genus to be described from Guinea. Based on chloroplast sequence data, the genus

26 is part of Clade II of tribe Pavetteae. In this clade, it is sister to Leptactina sensu lato (including

27 Coleactina and Dictyandra). Kindia gangan is distinguished from Leptactina s.l. by the

28 combination of the following characters: its epilithic habit; several-flowered axillary

29 inflorescences; distinct calyx tube as long as the lobes; a infundibular-campanulate corolla tube

30 with narrow proximal section widening abruptly to the broad distal section; presence of a dense

31 hair band near base of the corolla tube; anthers and style deeply included, reaching about mid-

32 height of the corolla tube; anthers lacking connective appendages and with sub-basal insertion;

33 pollen type 1; pollen presenter (style head) winged and glabrous (smooth and usually hairy in

34 Leptactina); orange colleters producing a vivid red exudate, which encircle the hypanthium, and

35 occur inside the calyx and stipules. Kindia is a subshrub that appears restricted to bare, vertical

36 rock faces of sandstone. Fruit dispersal and pollination by bats is postulated. It is here assessed as

37 Endangered EN D1 using the 2012 IUCN standard. High resolution LC-MS/MS analysis

38 revealed over 40 triterpenoid compounds in the colleter exudate, including those assigned to the

39 cycloartane class. Triterpenoids are of interest for their diverse chemical structures, varied

40 biological activities, and potential therapeutic value. 


\section{INTRODUCTION}

43 Plant conservation priorities are often poorly represented in national and global frameworks due

44 to a lack of publicly available biodiversity data to inform conservation decision making (Corlett,

45 2016; Darbyshire et al., 2017), despite the fact that one in five plant species are estimated to be

46 threatened with extinction mainly due to human activities (Brummitt et al., 2015; Bachman et al.,

47 2016). West Africa represents a priority target area for future efforts in botanical exploration to

48 inform conservation action and biological resource use (Sosef et al., 2017).

\section{Botanical exploration and new species discovery in Guinea}

51 Guinea has numerous endemic species and a high diversity of species in the context of West

52 Tropical African countries (c. 3000 species; Lisowski, 2009), including several endemic genera,

53 i.e. Fleurydora A.Chev. (Ochnaceae), Feliciadamia Bullock (Melastomataceae), Cailliella Jacq.-

54 Fél. (Melastomataceae). Botanical exploration, discovery and publication of new species

55 appeared to have nearly stopped after Independence in 1958, with the exception of the work

56 carried out by S. Lisowski (1924-2002). His work resulted in the publication of several new

57 species, e.g. Pseudoprosopis bampsiana Lisowski, Mikaniopsis camarae Lisowski and Bacopa

58 lisowskiana Mielcarek, and the posthumously published 'Flore de la République de Guinée'

59 (Lisowski, 2009). The other species new to science that were published in the period 1960-2010

60 were based on specimens collected in the French Colonial period, e.g. Phyllanthus felicis Jean

61 F.Brunel (1987) and Clerodendrum sylvae J.-G.Adam (1974). In recent years, this has begun to

62 change as botanical exploration, often associated with environmental impact assessments for

63 more environmentally responsible mining companies such as Rio Tinto (Harvey et al., 2010;

64 Magassouba et al., 2014), has restarted. Xysmalobium samoritourei Goyder (2009), 
65 Gymnosiphon samoritoureanus Cheek (Cheek \& van der Burgt, 2010), Eriosema triformum

66 Burgt (van der Burgt et al., 2012), Brachystephanus oreacanthus Champl. (Champluvier \&

67 Darbyshire, 2009), Striga magnibracteata Eb.Fisch. \& I.Darbysh. (Fischer et al., 2011),

68 Isoglossa dispersa I.Darbysh. \& L.J.Pearce (Darbyshire et al., 2012), Eriocaulon

cryptocephalum S.M.Phillips \& Mesterházy (Phillips \& Mesterházy, 2015), Napoleonea alata

70 Jongkind (Prance \& Jongkind, 2015) and Psychotria samouritourei Cheek (Cheek \& Williams,

71 2016) are examples of recent new discoveries from Guinea resulting from this impetus. Just

72 across the border in Mali, Calophyllum africanum Cheek \& Q.Luke (Cheek \& Luke, 2016) was

73 recently found, and in Ivory Coast Macropodiella cussetiana Cheek (Cheek \& Ameka, 2016).

74 Even a new rheophytic genus, Karima Cheek \& Riina has come to light in Guinea (Cheek et al.,

75 2016). Many of the new species being described are narrow endemics and are threatened by

76 habitat clearance for subsistence agriculture, open-cast mining, urban expansion, quarrying

77 (Couch et al., 2014) and invasive species (Cheek et al., 2013).

\section{Mt Gangan: a Tropical Important Plant Area}

80 The criteria of the Important Plant Areas (IPAs) programme, developed by Plantlife International

81 (2004), offer a pragmatic yet scientifically rigorous means of delivering biodiversity datasets,

82 enabling informed site-based conservation priorities (Darbyshire et al., 2017). IPAs are aligned

83 to Target 5 of the Convention on Biological Diversity (CBD)'s 'Global Strategy for Plant

84 Conservation' and so offer an important step towards fulfilling national CBD targets (Darbyshire

85 et al., 2017). IPAs are identified on the basis of three criteria: the presence of threatened species,

86 exceptional botanical richness and threatened habitats (Anderson, 2002; Plantlife International,

87 2004). These criteria were recently revised for a global approach (Darbyshire et al., 2017), and 
88 are used in the Tropical Important Plant Areas programme of the Royal Botanic Gardens, Kew.

89 In Guinea, botanical exploration is used to aid in aligning the existing forest reserve network,

90 which focuses on maintaining timber resources for exploitation, and the existing few National

91 Parks protecting large mammals or wetlands, to cover global priority areas for plant conservation.

92 The Mt Gangan area was identified as a prospective Tropical Important Plant Area

93 (Larridon \& Couch, 2016; Herbier National de Guinée, 2017; Darbyshire, continuously

94 updated). Mt Gangan is an outlier of the Fouta Djallon Highlands of Guinea, and is an area of

95 sandstone table mountains with sheer cliffs, frequent rock ledges, overhangs and caves. The rock

96 formations create a variety of microhabitats and are inhabited by sparse small trees, shrubs,

97 subshrubs and perennial herbs, many of which are rock specialists, such as Fegimanra afzelii

98 Engl. Fleurydora felicis A.Chev., Clerodendrum sylvae, Phyllanthus felicis, Cyanotis

99 ganganensis R.Schnell, Dissotis pygmaea A.Chev. \& Jacq.-Fél., Dissotis humilis A.Chev. \&

100 Jacq.-Fél. and Melastomastrum theifolium (G.Don) A.Fern. \& R.Fern var. controversum

101 (A.Chev. \& Jacq.-Fél.) Jacq.-Fél. (formerly Dissotis controversa (A.Chev. \& Jacq.-Fél.) Jacq.-

102 Fél.). Except Fegimanra afzelii, the abovementioned species are all either endemic or near-

103 endemic to the Mt Gangan complex of precipitous sandstone table mountains. Mt Gangan is also

104 home to Pitcairnia feliciana (A. Chev) Harms \& Mildbr., the only non-neotropical Bromeliaceae

105 (Porembski \& Barthlott, 1999).

\section{A new Rubiaceae from Mt Gangan}

108 In February 2016, a survey was initiated of the vegetation types, plant species, and threats at Mt

109 Gangan. During the survey an unusual Rubiaceae was observed with more or less sessile leaf

110 rosettes (Cheek 18345), growing only on vertical faces of bare sandstone cliffs that form the 
111 flanks of parts of some of the sandstone table mountains that comprise Mt Gangan (Fig. 1).

112 Cheek 18345 has fruits (Fig. 1) and only old, dried flowers. Because the old flowers were

113 mistakenly interpreted as likely to have had valvate corolla aestivation, and because the

114 inflorescences were axillary, with two-celled, fleshy fruits, containing numerous seeds, the

115 species was initially placed in tribe Mussaendeae sensu Hepper \& Keay (1963: 104), using the

116 key to the tribes of Rubiaceae in the Flora of West Tropical Africa. Within this tribe, it keyed out

117 as Sabicea Aubl. However, it matched no known species of that genus, being bizarre in several

118 features, such as the epilithic habit, the red colleter exudate, and the seeds with a central

119 excavation. Checks with all other genera of Rubiaceae in West Tropical Africa, and indeed

120 tropical Africa, also produced no matches, leading to the hypothesis that this taxon represented a

121 new genus to science. In June and September 2016, additional specimens (Cheek 18541A and

122 Cheek 18602) of the taxon were obtained during the flowering season, at which time the corolla

123 aestivation was found to be contorted to the left (Fig. 1), excluding it from Sabicea but consistent

124 with Pavetteae (De Block et al., 2015), as was first indicated by the results of the molecular study

125 (see below). However, the axillary inflorescences are unusual in that tribe (De Block et al., 2015).

126 In this study, morphological and chloroplast sequence data are employed to test the hypothesis

127 that the new Rubiaceae from Mt Gangan is: (1) part of tribe Pavetteae, and (2) represents a new

128 genus to science. To achieve this, we aim to investigate the overall morphology and the pollen

129 morphology and compare them to those found in other tribe Pavetteae genera, and place the

130 taxon in a molecular phylogenetic framework of the tribe. Ecology and conservation status of the

131 new Rubiaceae are also investigated, as is the colleter exudate biochemistry because of its

132 unusual red colour.

133 


\section{MATERIALS AND METHODS}

\section{Ethics statement}

136 The specimens studied were collected as a part of field surveys for the 'Important Plant Areas in

137 the Republic of Guinea' project funded by a Darwin Initiative grant of the Department of the

138 Environment, Food and Rural Affairs (DEFRA) of the government of the United Kingdom.

139 Permits to export these specimens were issued by the Ministère de l'Environnement et des Eaux

140 et Forêts of the Republic of Guinea, Certificat d'Origine $n^{\circ} 0000344$ (date 21 June 2016) and

$141 \mathrm{n}^{\circ} 0000399$ (dated 28 October 2016). Specimens were collected under the terms of a

142 Memorandum of Understanding between the Board of Trustees, RBG, Kew and the Herbier

143 National de Guinée, Université Gamal Abdel Nasser de Conakry, renewed and extended for 5

144 years in December 2015. The study area at Mt Gangan reported in this paper is controlled by the 145 government of the Republic of Guinea and is not privately owned, nor protected. The taxon 146 studied here is not yet a protected species.

\section{Taxonomy}

149 The electronic version of this article in Portable Document Format (PDF) will represent a 150 published work according to the International Code of Nomenclature for algae, fungi, and plants

151 (ICN), and hence the new names contained in the electronic version are effectively published

152 under that Code from the electronic edition alone. In addition, new names contained in this work

153 which have been issued with identifiers by IPNI (continuously updated) will eventually be made

154 available to the Global Names Index. The IPNI LSIDs can be resolved and the associated

155 information viewed through any standard web browser by appending the LSID contained in this

156 publication to the prefix "http://ipni.org/". The online version of this work is archived and 
157 available from the following digital repositories: PeerJ, PubMed Central, and CLOCKSS.

158

\section{Morphological study}

160 Herbarium material was examined with a Leica Wild M8 dissecting binocular microscope fitted

161 with an eyepiece graticule measuring in units of $0.025 \mathrm{~mm}$ at maximum magnification. The

162 drawing was made with the same equipment with a Leica 308700 camera lucida attachment. For

163 dissection, structures were first rehydrated by soaking in water with surfactant. The overall

164 morphology was documented, described and illustrated following botanical standard procedures

165 (Davis \& Heywood, 1963). Information about habit, habitat, and distribution was taken from

166 specimen labels and field observations.

168

169

170

171

172

173

174

175

176

177

178

179

Material of Cheek 18345, Cheek 18529, Cheek 18541A and Cheek 18602, the new

Rubiaceae of Mt Gangan, was first compared morphologically against reference material of all

Pavetteae genera held at $\mathrm{K}$. The study was then extended to include the BM, HNG, P and WAG herbaria. Codes for cited herbaria follow Index Herbariorum (Thiers, continuously updated). The main online search address used for retrieving specimen data from P (which globally has the largest holdings of herbarium specimens from the Republic of Guinea) was

https://science.mnhn.fr/institution/mnhn/collection/p/item/p00179355?listIndex=128\&listCount= 610; that for WAG was http://bioportal.naturalis.nl/geographic-search?language=en. Special focus was given to taxa shown to be closely related by the molecular phylogenetic results. All specimens marked '!' have been seen.

Pollen morphology has been shown to be useful in characterising clades, and sometimes genera within tribe Pavetteae (De Block \& Robbrecht, 1998). Pollen samples were collected from Cheek $18541 \mathrm{~A}(\mathrm{~K})$. Whole, unacetolysed anthers were placed on a stub using double-sided tape 
180 and sputter-coated with platinum in a Quorom Q150T coater for $30 \mathrm{~s}$ and examined in a Hitatchi

18154700 scanning electron microscope at an acceleration voltage of $4 \mathrm{kV}$.

182

\section{Molecular methods}

184 In this study, previously published chloroplast sequence data was used (De Block et al., 2015),

185 supplemented with new sequences from selected regions (rps16 and trnT-F) (Appendix 1). The

186 DNA extraction protocol and material and methods for amplification and sequencing used in this

187 study follow De Block et al. (De Block et al., 2015).

188 Sequences were assembled and edited in Geneious R8 (http://www.geneious.com; Kearse

189 et al., 2012), aligned using MAFFT 7 (Katoh, Asimenos \& Toh, 2009; Katoh \& Standley, 2013);

190 afterwards, alignments were checked manually in PhyDE 0.9971 (Müller et al., 2010). The

191 alignments used to produce the phylogenies are available as a Supplementary File Data S1.

192 Based on De Block et al. (2015), the alignments of the two chloroplast regions were

193 concatenated for the downstream analyses, each marker was treated as a separate partition, and

194 both partitions were analysed using the GTR+G model. Maximum likelihood (ML) analyses

195 were performed using RAxML 8.2.10 (Stamatakis, 2014). The search for an optimal ML tree

196 was combined with a rapid bootstrap analysis of 1000 replicates. Bayesian Inference (BI)

197 analyses were conducted in MrBayes 3.2.6 (Ronquist et al., 2012). Rate heterogeneity, base

198 frequencies, and substitution rates across partitions were unlinked. The analysis was allowed to

199 run for 100 million generations across four independent runs with four chains each, sampling

200 every 10000 generations. Convergence, associated likelihood values, effective sample size

201 values and burn-in values of the different runs were verified with Tracer 1.5 (Rambaut et al.,

202 2014). The first $25 \%$ of the trees from all runs were excluded as burn-in before making a 
203 majority-rule consensus of the 30000 posterior distribution trees using the "sumt" function. All

204 phylogenetic analyses were run using the CIPRES portal (http://www.phylo.org/; Miller, Pfeiffer

$205 \&$ Schwartz, 2010). Trees were drawn using TreeGraph2 (Stöver \& Müller, 2010) and FigTree

206 1.4.3 (Rambaut, 2016), and adapted in Adobe Photoshop CS5.

207

208 Ecology and conservation status

209 Field studies were conducted in the Mt Gangan complex north of Kindia in February (fruiting 210 season), June and September (flowering season) 2016, and in November 2017 (fruiting season).

211 Plants of the new taxon were mostly inaccessible on vertical sandstone cliffs, so were studied

212 and counted with binoculars. Voucher specimens were made in the usual way (Bridson \&

213 Forman, 1998) from the few accessible plants that could be reached from the base of the cliffs.

214 The conservation assessment was prepared following IUCN (2012) with the help of Bachmann et 215 al. (2011). The distribution of the species was mapped using SimpleMappr (Shorthouse \& David, 216 2010).

217

218 LC-MS/MS analysis of colleter exudate

219 A sample of Cheek 18345 was prepared by extracting the colleter exudate fragments in 220 EtOH:MeOH: $\mathrm{H}_{2} \mathrm{O}(5: 4: 1)(1 \mathrm{mg} / \mathrm{ml})$ for $24 \mathrm{~h}$, prior to centrifugation. The supernatant was then 221 subjected to LC-MS/MS analysis. Analyses were performed on a Thermo Scientific system 222 consisting of an 'Accela' U-HPLC unit with a photodiode array detector and an 'LTQ Orbitrap 223 XL' mass spectrometer fitted with an electrospray source (Thermo Scientific, Waltham, MA, 224 USA). Chromatography was performed with a $5 \mu 1$ sample injection onto a $150 \mathrm{~mm}$ x $3 \mathrm{~mm}, 3$

$225 \mu \mathrm{m}$ Luna C-18 column (Phenomenex, Torrance, CA, USA) using the following 400 $\mu 1 / \mathrm{min}$ 
226 mobile phase gradient of $\mathrm{H}_{2} \mathrm{O} / \mathrm{CH}_{3} \mathrm{CN} / \mathrm{CH}_{3} \mathrm{CN}+1 \% \mathrm{HCOOH}$ : 90:0:10 (0 min), 0:90:10 (20 min),

227 0:90:10 (25 $\mathrm{min})$, 90:0:10 (27 $\mathrm{min})$, 90:0:10 (30 $\mathrm{min})$. The ESI source was set to record high

228 resolution (30 k resolution) MS1 spectra $(\mathrm{m} / \mathrm{z} 125-2000)$ in negative mode and data dependent

229 MS2 and MS3 spectra using the linear ion trap. Detected compounds were assigned by

230 comparison of accurate mass data (based on $\mathrm{ppm}$ ), and by available MS/MS data, with reference

231 to the published compound assignment system (Schymanski et al., 2014).

232

233 RESULTS

234 Morphology

235 Characters separating the new Rubiaceae from Mt Gangan from its sister genus Leptactina are

236 provided in Table 1. A detailed description is given in the taxonomic treatment below.

The pollen grains (Fig. 2) are tricolporate, overall spheroidal, but usually triangular in

238 polar view 20-25 $\mu \mathrm{m}$ in diameter, with an apocolpium of 3.5-4.5 $\mu \mathrm{m}$ diameter, giving an

239 apocolpial index of 0.125 . The mesocolpium sculpturing is microperforate- reticulate, the

240 reticulum units are obscurely pentagonal, about $900-1000 \mathrm{~nm}$ in diameter, the muri broad and

241 rounded, the central perforations c. $0.1 \mu \mathrm{m}$. The apocolpium exine sculpturing grades to

242 microporate. The colpi are about 4-6 $\mu \mathrm{m}$ wide at the equator, $2 \mu \mathrm{m}$ wide at the poles. The colpal

243 membrane is densely granular, the granular units $0.2-0.5 \mu \mathrm{m}$ diameter, the margin with the

244 mesocolpium well-defined but irregular, and the pores 3-5 $\mu \mathrm{m}$ in diameter.

246 Molecular phylogeny

247 The concatenated ML and BI analyses did not significantly differ in topology, therefore the

248 results discuss the relationships shown in the majority consensus multiple-locus BI tree with the 
249

250

251

252

253

254

255

256

257

258

259

260

261

262

263

264

265

266

267

268

269

270

271

associated posterior probability (PP) values and the bootstrap (BS) values of the multiple-locus ML tree (Supplementary Fig. S1), and summarised in Fig. 3. As the data used here is largely based on the dataset used by De Block et al. (2015), the relationships recovered here largely match those published in that study. Within a well-supported tribe Pavetteae $(\mathrm{BS}=100, \mathrm{PP}=1)$, four major clades (I-IV) were retrieved. However, although in De Block et al. (2015) Clade I was retrieved as sister to a polytomy of Clades II-IV, in this study Clade $\mathrm{I}+\mathrm{III}(\mathrm{BS}=90, \mathrm{PP}=0.99)$ and Clade II+IV $(\mathrm{BS}=79, \mathrm{PP}=0.87)$ are supported as separate clades. Clade $\mathrm{I}(\mathrm{BS}=100, \mathrm{PP}=1)$ included the African genera Nichallea Bridson and Rutidea DC. Clade II $(\mathrm{BS}=100, \mathrm{PP}=1)$ comprised the African genus Leptactina Hook.f. sensu De Block et al. (2015) and the new Rubiaceae from Mt Gangan, with the latter sister to Leptactina of which the monophyly is well supported $(\mathrm{BS}=99, \mathrm{PP}=1)$. Clade III $(\mathrm{BS}=87, \mathrm{PP}=0.87)$ consisted of the paleotropical genus Pavetta L., the monotypic East African genus Cladoceras Bremek. and the African species of Tarenna Gaertn. In our BI analysis, the species Tarenna jolinonii N.Hallé was recovered as sister to the rest of a weakly supported Clade III, as was found in the results of De Block et al. (2015). However, in the ML analysis, this species was weakly supported as sister to Clade I. Clade IV $(\mathrm{BS}=92, \mathrm{PP}=1)$ included the East African monotypic genus Tennantia Verdc., Asian/Pacific and Madagascan species of Tarenna, the Madagascan endemics Homollea Arènes, Robbrechtia De Block and Schizenterospermum Homolle ex Arènes and the Afro-Madagascan genera Paracephaelis Baill. and Coptosperma Hook.f. As in the results of De Block et al. (2015), the nodes in this clade were poorly supported and the relationships between subclades remained unclear.

\section{LC-MS/MS analysis of colleter exudate}


272 High resolution LC-MS/MS analysis revealed the detection of a range of triterpenoids in the

273 exudate, including those assigned as the cycloartane class (Table 2). This included a compound

274 eluting at the retention time (Rt) $14.3 \mathrm{~min}$ with $\mathrm{m} / \mathrm{z} 499.3068$ that was assigned the molecular

275 formula $\mathrm{C}_{30} \mathrm{H}_{44} \mathrm{O}_{6}$ from the observed $[\mathrm{M}-\mathrm{H}]^{-}$ion, which is that of dikamaliartane $\mathrm{A}$, or isomer.

276 Four compounds eluting at Rt 23.8, 25.3, 25.9 and 26.9 min were assigned the molecular formula

$277 \mathrm{C}_{30} \mathrm{H}_{46} \mathrm{O}_{4}$, from their observed [M - H] $]^{-}$ions, which is that of dikamaliartane $\mathrm{D}, \mathrm{F}$, or isomer. The

278 cycloartane triterpenoids, dikamaliartanes A, D and F, have previously been reported to occur in

279 dikamali gum, which is the colleter exudate of Gardenia gummifera L.f. and G. resinifera Roth.

280 (Kunert et al., 2009), in the Rubiaceae.

Also detected in the colleter exudate of Cheek 18345 by LC-MS were two compounds

282 eluting at Rt 20.8 and 21.8 min that were both assigned the molecular formula $\mathrm{C}_{30} \mathrm{H}_{50} \mathrm{O}_{5}$ from

283 their observed $[\mathrm{M}-\mathrm{H}]^{-}$ions, which is that of gummiferartane 3, a cycloartane triterpenoid

284 previously reported to occur in G. gummifera $(C C D, 2017)$. Chemically related triterpenoids are

285 gummiferartanes 4 and 9 that have the molecular formula $\mathrm{C}_{30} \mathrm{H}_{48} \mathrm{O}_{4}$ and also occur in $G$.

286 gummifera $(C C D, 2017)$; four compounds were assigned with this molecular formula in the

287 colleter exudate, from their observed [M - H] ions, eluting at Rt 24.3, 24.9, 25.7 and $27.8 \mathrm{~min}$.

288 Other cycloartane triterpenoids have previously been reported to occur in species of Gardenia 289 (Kunert et al., 2009; CCD, 2017), with some of these in agreement with the molecular formulae 290 of the triterpenoids detected in the colleter exudate of Cheek 18345, as indicated in Table 2.

291 Other compounds detected in the colleter exudate of Cheek 18345 included those that 292 eluted at Rt $20.9 \mathrm{~min}$ with $\mathrm{m} / \mathrm{z}$ 463.3281, and at Rt $21.6 \mathrm{~min}$ with $\mathrm{m} / \mathrm{z} 391.3069$, that were 293 assigned the molecular formulae $\mathrm{C}_{24} \mathrm{H}_{48} \mathrm{O}_{8}$ and $\mathrm{C}_{20} \mathrm{H}_{42} \mathrm{O}_{4}$, respectively. These molecular 294 formulae are those of 1,2,3,4-octadecanetetrol; 1-O-rhamnoside and 1,2,3,4-eicosanetetrol, 
295 respectively, which have been reported as components of the resin from Commiphora species in 296 other studies, as indicated in Table 2.

297

298 DISCUSSION

299 Employing chloroplast sequence data of tribe Pavetteae, largely based on De Block et al. (2015),

300 placed the new Rubiaceae from Mt Gangan as sister to the rest of Clade II of that study, in which

301 three genera, Leptactina, Dictyandra Hook.f. and Coleactina N.Hallé were traditionally

302 maintained, although the two latter genera were recently subsumed into Leptactina s.l. (De Block

303 et al., 2015). Morphologically, the new Rubiaceae from Mt Gangan was consistent with these

304 genera, especially Leptactina s.s. and Coleactina, yet showed significant character disjunctions,

305 sufficient to support generic status. The new genus shares with the other members of Clade II

306 large broad stipules and large calyx lobes, large flowers with pubescent corollas, intrusive

307 placentas with numerous ovules and numerous small, angular seeds. However, morphological

308 differences are marked (Table 1), notably the winged, glabrous pollen presenter (versus smooth

309 and usually hairy in Leptactina s.l.), the absence of staminal connective appendages, the

310 difference in ratio of calyx tube:lobe (calyx tube well-developed and conspicuous in the new

311 taxon, versus absent or minute in Leptactina s.l except in Leptactina papalis (N.Hallé) De Block,

312 formerly Coleactina papalis N.Hallé), the seeds being bicolored (however, the state of this

313 character is unknown for several species of Leptactina and other Pavetteae), and the corolla tube

314 having a narrow proximal part and a much wider and longer distal part (possibly unique in

315 Pavetteae). The new Rubiaceae from Mt Gangan is atypical and differs from the standard state in

316 all other genera of Pavetteae by having several-flowered axillary inflorescences (Fig. 4). This has

317 been confirmed by observing the species during several seasons to ensure that the origin of the 
318 inflorescence is not terminal. However, some species of Pavetta, such as P. mayumbensis

319 Bremek. also have such inflorescences, possibly by contraction of the short branches that bear

320 terminal inflorescences in most species of that genus. The tribe is generally characterised by

321 terminal inflorescences (De Block et al., 2015). However, in Clade II, the remarkable monotypic

322 genus Coleactina from Gabon and the Republic of Congo, now included in Leptactina s.l., and

323 the species Leptactina deblockiae Neuba \& Sonké (Neuba et al., 2014) also have axillary

324 inflorescences, albeit 1-flowered and not several-flowered. Finally, the copious and conspicuous

325 bright red exudate from the apical bud of the new Rubiaceae from Mt Gangan appears to be

326 unique in Pavetteae and probably Rubiaceae. Colleter exudates are common in Rubiaceae, but

327 are usually inconspicuous. Conspicuous colleter-derived exudates are known in some genera in

328 tribe Coffeeae, e.g. Coffea L., and in genera of other tribes, such as Gardenia J.Ellis. Although

329 they are generally not reported in Pavetteae (Hallé, 1970; Bridson \& Verdcourt, 1988; De Block

330 et al., 2015), copious colleter exudate is present in the Madagascan Pavetteae genus Robbrechtia

331 (De Block, 2003), and colleter exudate has also been observed in several other Pavetteae genera

332 (P. De Block, pers. comm.). We have observed colleter exudates in some specimens of

333 Leptactina (e.g. Fofana 188, Jacques-Felix 7422, both from Guinea, Leptactina senegambica

334 Hook.f.; Goyder 6258, from Angola, Leptactina benguellensis (Benth. \& Hook.f.) Good, all K!).

335 As with all previously known Rubiaceae exudates except Gardenia (which is bright yellow,

336 Robbrecht pers. comm.), these are colourless or slightly yellow, and translucent, not bright red

337 and opaque as in the new Rubiaceae from Mt Gangan.

338 The palynological differences between Kindia and Leptactina s.l. are extensive. All

339 Leptactina s.l. have pollen type 2 (De Block \& Robbrecht, 1998), i.e. the grains are circular to

340 quadrangular in polar view, (3-)4-zonocolporate, with an apocolpial index of 0.39-0.68. In 
341 comparison, those of the new Rubiaceae from Mt Gangan are pollen type 1 (De Block \&

342 Robbrecht, 1998), since they are triangular in polar view (Fig. 2), 3-zonocolporate, with an

343 apocolpial index of 0.125 .

344 Possession of pollen type 1 by Cheek $18541 \mathrm{~A}$ rather than pollen type 2, is consistent with

345 its position as sister to Clade II since pollen type 1 'predominates in the whole of Rubiaceae and

346 can be considered primitive' (Robbrecht, 1988), that is, plesiomorphic. Pollen type 1 also occurs

347 in Pavetteae Clades III and IV (De Block \& Robbrecht, 1998; De Block et al., 2015). The four

348 apertures of pollen type 2 are considered as derived (De Block \& Robbrecht, 1998) and likely

349 represent a synapomorphy for Leptactina s.l. in Clade II.

350 With the discovery, characterisation and placement of the new Rubiaceae of Mt Gangan

351 as sister to Clade II, re-interpretation of the polarity of some characters in the rest of the clade is

352 in order. Features of Leptactina papalis, previously interpreted as apomorphies for the genus

353 Coleactina now appear to be plesiomorphic with regard to the newly discovered taxon. These are:

354 the well-developed calyx tube, and the pair of involucral cups (cupular bracts) surrounding the

355 ovary (Fig. 4H). Alternatively, these features may have evolved independently in both L. papalis

356 and the new taxon. Additional potentially plesiomorphic characters for Clade II are the axillary

357 inflorescences found in several Leptactina species including L. papalis and L. deblockiae (Neuba

358 et al., 2014), and the new Rubiaceae of Mt Gangan. The newly discovered lineage, sister to the

359 rest of Clade II, may represent an evolutionary relict, as it is only known from a single

360 morphologically and molecularly isolated species, which is rare, with less than 100 individuals

361 found in the wild. The unexpected discovery of this lineage from West Africa, sister to

362 Leptactina s.l., which is most diverse in terms of species and morphology in Central Africa, e.g.

363 in Gabon (Hallé, 1970) may also provide insights into the geographical origins of Clade II. 
365 its unusual epilithic habitat: narrow fissures in vertical sandstone cliff faces (Fig. 1A, B). In this

366 habitat, the well-developed aerial stems present in the rest of the tribe risk pulling the plants, by

367 their mass, from the tiny fissures and pockets in which they are rooted. This circumstance

368 appears to parallel the situation of Mussaenda epiphytica Cheek (tribe Mussaendeae, Rubiaceae;

369 Cheek, 2009), a rare epiphytic species, similarly threatened with extinction (Onana \& Cheek,

2011; Lachenaud et al., 2013), in a genus of shrubs and twining terrestrial climbers. Mussaenda

epiphytica also appears to have mostly lost its ability to produce long stems, which was similarly

conjectured to be disadvantageous in an epiphytic life form (Cheek, 2009). Several species of

Leptactina are also subshrubs of nearly similar small stature to the new taxon, but these species

374 have underground rootstocks and are terrestrial.

Plant exudates, including resins and gums, can occur as complex mixtures of different compound classes including carbohydrates, mono-, di- and tri-terpenoids (Rhourrhi-Frih et al., 2012). In this study, the colleter exudate of the new Rubiaceae from Mt Gangan was subjected to high resolution LC-MS/MS analysis for the first time to investigate the chemical composition and over 40 triterpenoids were detected including those assigned as the cycloartane class. These included those with the molecular formulae of dikamaliartanes A, D and F, or their isomers. The cycloartane triterpenoids, dikamaliartanes A-F have previously been subjected to antimicrobial assays using Staphylococcus aureus, Candida albicans and Mycobacteria but they did not reveal significant activity against these human pathogens (Kunert et al., 2009). Any potential role they may have against plant pathogens or as defence compounds requires further evaluation. that cyclization of of $(3 S)$-squalene 2,3-epoxide in higher plants occurs with formation of 
387 cycloartenol, which has been considered to have a role in sterol biosynthesis, analogous to that of

388 lanosterol in animals and fungi (Boar \& Romer, 1975). Furthermore, some plant triterpenoids,

389 including those derived from cycloartane, have been suggested to have a function in cell

390 membrane composition (Nes \& Heftmann, 1981), thus any evolutionary role they may have in

391 members of the new Rubiaceae from Mt Gangan would be of interest to explore in further

392 studies. Many triterpenoids of plant origin have been of interest for their chemical diversity,

393 biological activities and potential therapeutic applications (Hill \& Connolly, 2017; Howes, 2018).

394 The triterpenoids detected in the exudate in this study would be of interest to explore further, not

395 only for their biological activities that might aid understanding of their rationale for synthesis by

396 this species, but also for their potential uses by humanity, if this can be done in a way consistent

397 with the conservation of this rare and threatened species.

398

399 TAXONOMIC TREATMENT

400 Kindia Cheek, gen nov.

401 Type: Kindia gangan Cheek

402 Diagnosis: differs from Leptactina s.l. in a corolla tube with a slender proximal part and an

403 abruptly much wider, longer distal part (not more or less cylindrical, or gradually widening); a

404 glabrous, winged pollen-presenter (not hairy, non-winged); an epilithic habit (not terrestrial,

405 growing in soil); a conspicuous opaque red colleter exudate (not translucent and colourless or

406 slightly yellow); and type 1 pollen (not type 2) (De Block \& Robbrecht, 1998).

407

408 Epilithic subshrub, lacking underground rootstock. Stems short, unbranched, erect or appressed

409 to substrate, reiterating from base, completely sheathed in marcescent stipules, stem indumentum 
410 simple, short. Leaves opposite, petiolate, equal in shape and size at each node, each stem with 2

4113 pairs of leaves held \pm appressed to the vertical substrate; blades simple, entire; domatia absent;

412 nervation pinnate; stipules broadly ovate, midline with a raised ridge; base of adaxial surface

413 with a mixture of hairs and standard type colleters (Robbrecht, 1988) producing a vivid red

414 exudate from the apical bud, conspicuous in dried specimens. Inflorescences axillary, opposite,

415 in successive nodes, pedunculate-fasciculate, 1-4(-6)-flowered; bracts cupular, 2, sheathing,

416 each with two large and two small lobes (Fig. 4H). Flowers 5-merous, homostylous. Ovary-

417 hypanthium sessile, cylindric, with a ring of orange colleters inserted above the base, continuous

418 with the calyx tube and about twice as long as broad; inside of the calyx tube with dense band of

419 colleters at base, calyx lobes 5, oblong-elliptic, about as long as tube. Corolla nearly twice as

420 long as calyx; tube infundibular-campanulate, exceeding calyx; outer surface densely sericeous,

421 inner surface subglabrous apart from a dense band of hairs just above the base; corolla lobes 5 , at

422 anthesis elliptic-oblong, arching outwards (appearing broadly ovate when viewed from above Fig.

423 1C), with apiculus, post-anthesis drying elliptic-triangular (Fig. 4I), about one third as long as

424 tube, aestivation contorted to the left in bud. Stamens adnate to the corolla tube, five, inserted

425 midway up corolla tube, alternating with corolla lobes; anthers narrowly oblong, sessile, attached

426 near base, apical appendage not developed. Ovary 2-celled, placentation axile; placentae

427 intrusive, swollen, ovules numerous; style included, distal half hairy, basal part glabrous; pollen

428 presenter (stylar head) dilated, outer surface glabrous, fluted-ridged, with two appressed

429 stigmatic lobes at apex, apices tapering, acute, at same level as anthers. Fruit globose, ripening

430 greenish-yellow or white, glossy, semi-translucent, outer surface hairy; pericarp succulent, thick,

431 calyx persistent. Seeds numerous, truncated, 4-5-sided pyramidal (frustrums) glossy black; hilar

432 area white, deeply excavated with a thickening inside; embryo occupying c. 5-10\% of the seed 
433 volume, horizontal, cotyledons barely detectable.

434

435 Kindia gangan Cheek sp. nov. -Figs. 1, 4

436 Type. Republic of Guinea, Kindia Prefecture, Mt Gangan area, Kindia-Télimelé Rd, km 7, N of

437 Mayon Khouré village, fr. 5 Feb. 2016, Cheek 18345 (holotype HNG!, isotypes BR!, K!, P!, 438 US!).

Perennial epilithic subshrub, multi-stemmed from base. Stems very short, appressed to substrate

441 or sometimes pendulous, not rooting at the nodes, woody, reiterating from base, completely

442 sheathed in persistent dark brown stipules, 5-6(-35) cm long, each stem with 2-3 pairs of leaves

443 held \pm appressed to the substrate; internodes (2.5-)5 mm long, 5-7 mm diam.; indumentum

444 composed of short white patent hairs, 0.1-0.2 mm long. Leaves opposite, equal in shape and size

445 at each node; blade elliptic (-obovate), (7.5-)9.4-11.7 × (3.2-)4.2-6.6(-7) cm; apex obtuse to

446 shortly acuminate, acumen 1-2 mm long; base acute, abruptly decurrent to the upper 2-5 $\mathrm{mm}$ of

447 the petiole; upper blade surface bullate; indumentum white, subappressed, $0.1-0.3 \mathrm{~mm}$ long, $30 \%$

448 cover; midrib hairs $0.3-0.4 \mathrm{~mm}$ long, $80 \%$ cover; midrib c. $1 \mathrm{~mm}$ broad, yellow drying white;

449 secondary nerves (7-)8-10(-11) on each side of the midrib; lower surface of blade with

450 indumentum as upper, denser, c. 40\% cover; midrib 1.2-1.3 mm wide, showing 3 distinct

451 longitudinal areas; the central area raised, convex, $40 \%$ covered in hairs; the lateral areas flat, $90 \%$

452 covered in hairs; domatia absent; secondary nerves arising at c. $60^{\circ}$ from the midrib, curving near

453 the margin and looping towards the leaf apex and uniting with the nerve above

454 (brochidodromous); tertiary nerves conspicuous, raised, white puberulent scalariform (5-)6-8

455 between each pair of secondary nerves; quaternary nerves apparent only in the tertiary cells 
456 (areolae) towards the margin, each tertiary cell with 8-12 bullae (not always visible in the

457 pressed specimens). Petiole semi-circular in transverse section, 3-4 mm long at the distal-most

458 node, elongating to 6-10(-14) $\mathrm{mm}$ long at the second and third node from the apex. Interpetiolar

459 stipules broadly ovate $3-5.5 \times 3-5 \mathrm{~mm}$; apex acute or rounded to shortly acuminate; outer

460 surface midline with a raised ridge; indumentum as upper surface of leaf blade; adaxial surface

461 with colleters in line at the base, producing a vivid red exudate over the apical bud, conspicuous

462 in dried specimens; colleters standard type (Robbrecht 1988), orange, cylindric, $0.5-1.5 \times 0.2$

$463 \mathrm{~mm}$ long, gradually tapering to a rounded apex, interspersed with bristly hairs $1-2 \mathrm{~mm}$ long at

464 stipule base, otherwise hairs sparse, $0.2-0.4 \mathrm{~mm}$ long, 10-20 \% cover. Inflorescences axillary,

465 opposite, and in successive nodes, pedunculate-fasciculate, 1-4(-6)-flowered. Peduncle 4-15 $\times$

$4661.5-2.5 \mathrm{~mm}$; indumentum as upper surface of leaf-blade; bracts cupular, 2, outer (proximal) bract

467 sheathing and concealing the smaller inner (distal) bract, 3.5-4 × 5-7 mm, 4-lobed, with the

468 large lobes (presumed of stipular origin) oblong-elliptic $4.5-6.5 \times 2.5 \mathrm{~mm}$ and the short lobes

469 (presumed of leaf origin) triangular, 1-2 $\times 2 \mathrm{~mm}$. Ovary-hypanthium sessile (pedicel absent),

470 partly concealed, and sunken in the axis below the insertion of the distal cupular bract (ovary

471 locules extending below the junction of ovary with distal cupular bract), free part (that part

472 which is not sunken into the axis) subcylindrical, $2 \mathrm{~mm}$ long, $4 \mathrm{~mm}$ in diameter at junction with

473 calyx, hairs white, more or less patent, $0.5 \mathrm{~mm}$ long; ring of orange colleters $0.5-0.75 \mathrm{~mm}$ long,

474 appressed, inserted about $1 / 3$ up from base; calyx tube $(3-) 4-5(-10) \times 4-5 \mathrm{~mm}$ at base, $5-6(-10)$

$475 \mathrm{~mm}$ wide at apex; calyx lobes 5, oblong elliptic, 7-11 $\times 2-3(-4.5) \mathrm{mm}$, apex acute; indumentum

476 on both surfaces $0.4-0.6(-1.1) \mathrm{mm}$ long more or less patent, c. $50 \%$ cover on tube, $20-30 \%$

477 cover on lobes; inner surface also with a dense band of colleters at base, extending in lines a

478 short distance up from the base of the calyx tube. Corolla white, infundibular-campanulate, 3- 
$4794.5 \mathrm{~cm}$ long pre-anthesis, at anthesis with lobes splayed, $4.2-4.3 \mathrm{~cm}$ wide at mouth including the

480 lobes; outer surface of corolla densely pale brown sericeous, hairs $0.5 \mathrm{~mm}$ long, covering the

481 surface; tube with two distinct sections, proximal and distal; proximal section slender, $6 \times 2 \mathrm{~mm}$,

482 glabrous inside in proximal part, middle portion of the proximal tube with a densely puberulent

483 band $1-2 \mathrm{~mm}$ long, hairs white $2 \mathrm{~mm}$ long forming a seal with the style; distal section of corolla

484 tube abruptly wider, $2.2-2.6 \times 1.4-1.6 \mathrm{~cm}$, inner surface of distal section glabrous in proximal

$4852.2-2.4 \mathrm{~cm}$, distalmost part of tube (at mouth) with thinly scattered hairs $0.1-0.2 \mathrm{~mm}$ long, 30-

$48640 \%$ cover; lobes 5 , glabrous inside, oblong-elliptic (appearing broadly ovate when viewed from

487 above as in Fig. 1C), 9-12 × 6.5-9(-16) $\mathrm{mm}$, then extending into a filiform appendage $3-4 \mathrm{~mm}$

488 long, apex acute, margins becoming involute post-anthesis. Stamens five, alternating with corolla

489 lobes; anthers sessile, elliptic c. 5-6 × $1 \mathrm{~mm}$, attached near the base and inserted $1.5 \mathrm{~cm}$ from

490 corolla base. Disc bowl-shaped, $1 \mathrm{~mm}$ wide, $2 \mathrm{~mm}$ deep, glabrous, smooth. Ovary 2-celled,

491 placentation axile; placentae intrusive, shield-shaped, $2 \times 1.25 \mathrm{~mm}, 0.5 \mathrm{~mm}$ thick (including

492 ovules); ovules 40-50 per locule, elliptic, $0.25 \mathrm{~mm}$ long; style included, $2.2 \mathrm{~cm}$ long, $1 \mathrm{~mm}$ diam.

493 at base, proximal 9-9.5 mm glabrous, median 5-6 $\mathrm{mm}$ patent-hairy with hairs $0.3-0.5 \mathrm{~mm}$ long,

494 distal 10.5-11 mm glabrous; pollen presenter (stylar head) dilated, with two appressed lobes $3 \times$

495 1-1.2 mm, outer surface fluted-ridged, apices tapering, acute. Fruit globose, 9-10 mm diam.

496 sessile, ripening greenish-yellow or white, glossy, semi-translucent, outer surface with appressed

497 white hairs $0.6-0.9 \mathrm{~mm}$ long; pericarp succulent, 2-3 mm thick, calyx persistent. Seeds

498 numerous 30-50 per fruit, truncated, 4-5-sided, pyramid (frustum), 1.5-2 $\times 1.5-2 \times 1.5 \mathrm{~mm}$, the

499 proximal (hilar end) white, the distal two-thirds glossy black; epidermis with finger-print surface

500 pattern embryo minute, c. $0.3 \mathrm{~mm}$ long, cotyledons about 1/4 of length, not well demarcated. 


\section{Distribution}

503 République de Guinée, Kindia Prefecture, northeastern boundary of Mt Gangan area, west of

504 Kindia-Telimélé Rd (Fig. 5).

505

506 Ecology

507 The area of the Mt Gangan complex in which we found plants of Kindia consists of two parallel 508 ranges of small sandstone table mountains separated by a narrow N-S valley that appears to be a 509 geological fault. Bedding of the sandstone is horizontal. Uneven erosion on some slopes has

510 resulted in the formation of frequent rock ledges, overhangs and caves. In contrast other flanks of

511 the mountains are sheer cliffs extending 100 metres or more high and wide. It is on the cliff areas

512 at 230-540 $\mathrm{m}$ a.s.1 that Kindia gangan occurs as the only plant species present, usually as

513 scattered individuals in colonies of (1-3-)7-15 plants, on the bare expanses of rock that are

514 shaded for part of the day due to the orientation of the cliffs or to overhangs or due to a partial

515 screen of trees in front of the rockfaces. Pitcairnia feliciana (Bromeliaceae), in contrast is found

516 in fully exposed sites where there is, due to the rock bedding, a horizontal sill in which to root.

517 These two species can grow within metres of each other if their cliff microhabitats occur in

518 proximity. The rock formations create a variety of other microhabitats, including vertical fissures,

519 caves, shaded, seasonally wet ledges, and are inhabited by sparse small trees, shrubs, subshrubs, 520 perennial and annual herbs, many of which are narrow endemic rock specialists. We speculate

521 that the seed of this species might be bat-dispersed because of the greenish yellow-white colour

522 of the berries (less attractive to birds than fruits which are e.g. red or black) and the position of

523 the plants high on cliff faces, where nothing but winged creatures could reach them, apart from

524 those few plants at the base of the cliffs. However, fruit dispersal is not always effected since we 
525 found numerous old dried intact fruits holding live seeds on the plants at the type locality in

526 February 2016. It is possible that the robust, large white flowers are pollinated by a small species

527 of bat since in June and September we saw signs of damage to the inner surface of the corolla

528 inconsistent with visits by small insects. The damage takes the form of brown spots on the inner

529 surface of the corolla tube. Freshly opened flowers do not have these spots, nor do all flowers,

530 only those few which show slight damage. The very broad, short corolla is not consistent with

531 pollination by sphingid moths (which prefer long, slender-tubed flowers), but this cannot be

532 ruled out.

533

534 Local names and uses

535 None are known. The local communities in the area when interviewed in November 2017, stated 536 that they had no uses nor names for the plant (Molmou \& Doré, pers. obs.).

538 Etymology

539 The genus is named for the town and prefecture of Kindia, Guinea's fourth city, and the species

540 is named for Mt Gangan to its north, which holds the only known location for the species. Both 541 names are derived as nouns in apposition.

542

\section{Conservation status}

544 Knowledge of Kindia gangan is based on 15 days of searching in sandstone rock outcrops

545 around the Mt Gangan complex in 2016-2017 by teams each comprising 3-5 botanists, together

546 with local community representatives. This area was previously visited by several excellent

547 botanists in the colonial period, notably by Jacques-Félix in 1934-37. Only 86 mature plants of 
548 Kindia gangan were seen at seven sites at two locations (as defined by IUCN, 2012). The two

549 locations are separated by $19 \mathrm{~km}$. Within locations, the sites are separated by $150 \mathrm{~m}-1.5 \mathrm{~km}$.

550 The Extent of Occurrence and Area of Occupancy were calculated as $27.96 \mathrm{~km}^{2}$ and $20 \mathrm{~km}^{2}$

551 respectively (Bachmann et al., 2011). At each site (1-7-)10-20 plants occur gregariously.

552 Accordingly, since less than 250 mature individuals are known of this species, it is here assessed

553 as Endangered under Criterion D1 of IUCN (2012). It is to be hoped that more plants will be

554 found, enabling a lower assessment of the threat to this species. Currently, threats to the plants at

555 the two known locations of this species are low. Quarrying of sandstone for building

556 construction in nearby Kindia, Guinea's fourth city occurs nearby, but fortunately one of the

557 locations of Kindia gangan has no road access, so the known plants are not immediately

558 threatened, while at the second location, plants are within reach of roads and so more threatened

559 by future quarrying. It is to be hoped that further sites for the species will be found, lowering the

560 extinction risk of the species. As a precautionary measure it is intended to feature the species in a

561 poster campaign to raise public awareness, and to seedbank it in the newly created seed bank at

562 the University of Gamal Abdel Nasser, Conakry and also at the Royal Botanic Gardens, Kew.

563

564 Additional specimens examined

565 Republic of Guinea, Kindia Prefecture, Mt Gangan area, Mt Gnonkaoneh, NE of Mayon Khoure

566 village which is W of Kindia-Télimelé rd., fl. 19 June 2016, Cheek 18529 (HNG!, K!); Mt

567 Khonondeh, NW of Mayon Khoure village which is W of Kindia to Télimelé rd., fl. 20 June

568 2017, Cheek 18545 (HNG!, K!). Mt Gnonkaoneh, NE of Mayon Khoure village, fl. 30 Sept.

569 2016, Cheek 18602 (HNG!, K!); near Kalakouré village, Kindia-Télimelé rd, fr. 1 Nov. 2017,

570 Doré 136 (HNG!, K!); Sougorunyah near Fritaqui village, fr. 6 Nov. 2017, Molmou 1669 (HNG!, 
571 K!); Kebe Figuia near Fritaqui village, fr. 6 Nov. 2017, sight observation by Doré and Molmou.

572 Additional observation (photo record): Mt Khonondeh, NW of Mayon Khoure village which is

573 W of Kindia to Télimelé rd., fl. 20 June 2017, Cheek 18541A.

574

575 CONCLUSIONS

576 Kindia, an endangered subshrub, restricted to bare, vertical rock faces of sandstone is described 577 and placed in Clade II of tribe Pavetteae as sister to Leptactina s.l. based on chloroplast sequence 578 data. The only known species, Kindia gangan, is distinguished from the species of Leptactina s.l.

579 by a combination of characters: an epilithic habit; several-flowered axillary inflorescences;

580 distinct calyx tube as long as the lobes; a infundibular-campanulate corolla tube with narrow

581 proximal section widening abruptly to the distal section; presence of a dense hair band near base

582 of the corolla tube; anthers and style deeply included, reaching about mid-height of the corolla

583 tube; anthers lacking connective appendages and with sub-basal insertion; pollen type 1; pollen

584 presenter winged and glabrous; orange colleters, which encircle the calyx-hypanthium, occur at

585 base and inside the calyx and stipules and produce vivid red exudate. High resolution LC-

$586 \mathrm{MS} / \mathrm{MS}$ analysis revealed over 40 triterpenoid compounds in the colleter exudate, including

587 those assigned to the cycloartane class. Triterpenoids are of interest for their diverse chemical

588 structures, varied biological activities, and potential therapeutic value.

589

590 ACKNOWLEDGEMENTS

591 Professor Basile Camara, former Director General of the Université Gamal Abdel Nasser de

592 Conakry-Herbier National de Guinée, is thanked for arranging permits and for his long term

593 support and collaboration. Janis Shillito is thanked for typing the manuscript. Charlie Gore 
594 assisted with scanning electron microscopy. The authors would like to thank Dr Geoffrey C. Kite, 595 Royal Botanic Gardens, Kew, for acquiring the LC-MS data. Three reviewers, Ds Petra De

596 Block, Dr Olivier Lachenaud and Prof. Elmar Robbrecht are thanked for constructive comments 597 on earlier drafts of the paper.

598

599 APPENDIX 1

600 Sampled plants and DNA sequences. For each plant the provenance, followed by collector and 601 collector number, herbarium for deposition of voucher specimen (in parentheses), and GenBank 602 accession numbers for rps16 and trnT-F. FTEA: Flora of tropical East Africa. Abbreviation 's.n.' 603 indicates no collection number. The newly generated sequences are in bold.

604 Tribe Alberteae: Razafimandimbisonia humblotii (Drake) Kainul. \& B.Bremer605 Madagascar, Tosh et al. 263 (BR), KM592238, KM592145.

606 Tribe Coffeeae: Tricalysia semidecidua Bridson-Zambia, Dessein et al. 1093 (BR), 607 KM592279, KM592185.

Tribe Ixoreae: Ixora sp. -Thailand, Sudde 1487 (K), KM592208, KM592115.

609

Tribe Gardenieae: Euclinia longiflora Salisb.-Africa (country unknown), Van

610 Caekenberghe 348 (BR), KM592203, KM592110.

611 Gardenia rutenbergiana (Baill. ex Vatke) J.-F.Leroy-Madagascar, Groeninckx et al. 24 612 (BR), KM592204, KM592111.

613 Oxyanthus troupinii Bridson-Burundi, Niyongabo 115 (BR), KM592219, KM592126.

614 Tribe Mussaendeae: Pseudomussaenda flava Verdc._Africa (country unknown), Van

615 Caekenberghe 60 (BR), KM592217, KM592124.

616 Tribe Pavetteae: Cladoceras subcapitatum (K.Schum. \& K.Krause) Bremek.-Tanzania, 
617 Luke et al. 8351 (UPS), AM117290, KM592094.

618 Coptosperma bernierianum (Baill.) De Block-Madagascar, Schatz et al. 3764 (MO),

619 KJ815340, KJ815589; C. borbonicum (Hend. \& Andr.Hend.) De Block-Comores, De Block

6201389 (BR), KM592189, KM592096; C. borbonicum (Hend. \& Andr.Hend.) De Block-Réunion,

621 Kainulainen 189 (S), KJ815342, KJ815591; C. borbonicum (Hend. \& Andr.Hend.) De Block-

622 Unknown, Kroger et al. 56 (S), KJ815341, KJ815590; C. cymosum (Willd. ex Schult.) De

623 Block-Mauritius, Razafimandimbison et al. 843 (S), KJ815343, KJ815592; C. graveolens

624 (S.Moore) Degreef-Kenya, Mwachala 3711 (BR), KM592200, KM592107; C. humblotii

625 (Drake) De Block-Madagascar, Bremer et al. 5167 (S), KJ815345, KJ815594; C. littorale

626 (Hiern) Degreef-Mozambique, Luke et al. 9954 (UPS), KM592190, KM592097; $\boldsymbol{C}$.

627 madagascariense (Baill.) De Block-Madagascar, De Block et al. 2238 (BR), KM592191,

628 KM592098; C. madagascariense (Baill.) De Block-Madagascar, Razafimandimbison 527

629 (UPS), KM592191, KM592098; C. mitochondrioides Mouly \& De Block-Madagascar, Bremer

630 et al. 5127 (S), KJ815348, KJ815597; C. nigrescens Hook.f.-Madagascar, De Block et al. 535

631 (BR), KM592192, KM592099; C. nigrescens Hook.f.-Kenya, Luke \& Luke 9030 (UPS),

632 KM592193, KM592100; C. peteri (Bridson) Degreef-Tanzania, Lovett \& Congdon 2991 (BR),

633 KM592201, KM592108; C. supra-axillare (Hemsl.) Degreef-Madagascar, De Block et al. 1321

634 (BR), KM592194, KM592101; C. sp. nov. A-Madagascar, De Block et al. 720 (BR),

635 KM592199, KM592106; C. sp. nov. B-Madagascar, De Block et al. 796 (BR), KM592195,

636 KM592102; C. sp. nov. C-Madagascar, De Block et al. 1355 (BR), KM592196, KM592103; $\boldsymbol{C}$.

637 sp. nov. D-Madagascar, De Block et al. 704 (BR), KM592197, KM592104; C. sp. nov. E-

638 Madagascar, De Block et al. 733 (BR), KM592198, KM592105.

639 Homollea longiflora Arènes-Madagascar, De Block et al. 767 (BR), KM592205, 
640 KM592112; H. perrieri Arènes-Madagascar, Morat 4700 (TAN), KM592206, KM592113.

641 Kindia gangan Cheek-Republic of Guinea, Cheek 18345 (K),MG708505, MG708506.

642 Leptactina arborescens (Welw. ex Benth. \& Hook.f.) De Block-Ghana, Schmidt et al.

6431683 (MO), KM592202, KM592109.; L. benguelensis (Welw. ex Benth. \& Hook.f.)

644 R.D.Good-Zambia, Dessein et al. 1142 (BR), KM592209, KM592116; L. delagoensis K.Schum.-

645 Tanzania, Luke \& Kibure 9744 (UPS), KM592210, KM592117; L. epinyctios Bullock ex

646 Verdc.-Zambia, Dessein et al. 1348 (BR), KM592211, KM592118; L. involucrata Hook.f.-

647 Cameroon, Davis 3028 (K), KM592212, KM592119; L. leopoldi-secundi Büttner-Republic of

648 Congo, Champluvier 5248 (BR), KM592213, KM592120; L. mannii Hook.f.-Gabon, Dessein

649 et al. 2518 (BR), KM592214, KM592121; L. papalis (N.Hallé) De Block-Gabon, Dessein et al.

6502355 (BR), KM592188, KM592095; L. papyrophloea Verdc.-Tanzania, Luke \& Kibure 9838

651 (UPS), KM592215, KM592122; L. pynaertii De Wild.-Republic of the Congo, Champluvier s.n.

652 (BR), KM592216, KM592123.

653 Nichallea soyauxii (Hiern) Bridson-Cameroon, Dessein et al. 1402 (BR), KM592218,

654 KM592125.

655 Paracephaelis cinerea (A.Rich. ex DC.) De Block-Madagascar, De Block et al. 2193

656 (BR), KM592220, KM592127; P. cinerea (A.Rich. ex DC.) De Block-Madagascar, Bremer et

657 al. 5122 (S), KJ815372, KJ815619; P. saxatilis (Scott-Elliot) De Block-Madagascar, De Block

658 et al. 2401 (BR), KM592221, KM592128; P. saxatilis (Scott-Elliot) De Block-Madagascar,

659 Razafimandimbison \& Kroger 937 (S), KJ815374, KJ815622; P. sericea (Arènes) De Block,

660 Madagascar, De Block et al. 849 (BR), KM592207, KM592114; P. tiliacea Baill.-Madagascar,

661 Groeninckx et al. 113 (BR), KM592222, KM592129; P. trichantha (Baker) De Block-Aldabra

662 (Seychelles), Friedmann 833385 (UPS), KJ815376, KJ815624; P. sp.-Madagascar, De Block 
6631174 (BR), AM117331, KJ815620.

664 Pavetta abyssinica Fresen.-Africa (unknown country), De Block 6 (BR), FM204726,

665 FM207133; P. agrostiphylla Bremek.-Sri Lanka, Bremer B. \& K. 936 (UPS), KM592223,

666 KM592130; P. batesiana Bremek.-Gabon, Dessein et al. 2071 (BR), KM592224, KM592131;

667 P. hymenophylla Bremek.-Tanzania, Luke et al. 9101 (UPS), KM592225, KM592132; $\boldsymbol{P}$.

668 indica L.-Sri Lanka, Andreasen 202 (UPS), KM592226, KM592133; P. sansibarica

669 K.Schum.-Kenya, Luke et al. 8326 (UPS), KM592227, KM592134; P. schumanniana F.Hoffm.

670 ex K.Schum.-Zambia, Dessein et al. 911 (BR), KM592228, KM592135; P. stenosepala

671 K.Schum.-Kenya, Luke et al. 8318 (UPS), KM592233, KM592140; $\boldsymbol{P}$. suffruticosa

672 K.Schum.-Cameroon, Lachenaud et al. 838 (BR), KM592231, KM592138; P. tarennoides

673 S.Moore-Kenya, Luke et al. 8325 (UPS), KM592234, KM592141; P. ternifolia Hiern-Burundi,

674 Ntore 19 (BR), KM592235, KM592142; P. tetramera (Hiern) Bremek-Gabon, Van de Weghe

675163 (BR), KM592236, KM592143; P. vaga S.T.Reynolds-Australia, Harwood 1290 (DNA),

676 KM592237, KM592144; P. sp. A of FTEA Bridson-Tanzania, Luke et al. 9134 (UPS),

677 KM592232, KM592139; $\boldsymbol{P}$ sp. $\boldsymbol{B}$-Vietnam, Davis et al. 4082 (K), KM592229, KM592136; $\boldsymbol{P}$.

678 sp. $C$-Asia (country unknown), Van Caekenberghe 199 (BR), KM592230, KM592137.

679 Robbrechtia grandifolia De Block-Madagascar, Kårehed 311 (UPS), KM592239,

680 KM592146; R. milleri De Block-Madagascar, Bremer et al. 5295 (S), KM592240, KM592147.

$681 \quad$ Rutidea decorticata Hiern-Cameroon, Maurin 14 (K), KM592241, KM592148; $\boldsymbol{R}$.

682 dupuisii De Wild.-Gabon, Dessein et al. 1802 (BR), KM592242, KM592149; R. ferruginea

683 Hiern-Cameroon, Dessein et al. 1674 (BR), KM592242, KM592150; R. fuscescens Hiern-

684 Tanzania, Luke et al. 9124 (UPS), KM592244, KM592151; R. membranacea Hiern-Liberia,

685 Adam 21433 (UPS), KM592245, KM592152; R. olenotricha Hiern-Ghana, Schmidt et al. 1731 
686 (MO), KM592246, KM592153; R. parviflora DC.-Liberia, Adam 20156 (UPS), KM592248,

687 KM592154; R. seretii De Wild.-Cameroon, Gereau 5588 (UPS), KM592249, KM592155.

688 Schizenterospermum grevei Homolle ex Arènes-Madagascar, De Block et al. 2167

689 (BR), KM592250, KM592156; S. rotundifolia Homolle ex Arènes-Madagascar, De Block et al. 690771 (BR), KM592251, KM592157.

691 Tarenna alleizettei (Dubard \& Dop) De Block-Madagascar, De Block et al. 1883 (BR),

692 KM592272, KM592178; T. alleizettei (Dubard \& Dop) De Block-Madagascar, Kårehed 313A

693 (UPS), KJ815382, KJ815630; T. alpestris (Wight) N.P.Balakr._India, De Block 1474 (BR),

694 KM592252, KM592158; T. asiatica (L.) Kuntze ex K.Schum.-India, Auroville 998 (SBT),

695 KM592253, KM592159; T. bipindensis (K.Schum.) Bremek., Liberia, Jongkind 8495 (BR),

696 KM592255, KM592161; T. capuroniana De Block-Madagascar, De Block et al. 937 (BR),

697 KM592273, KM592179; T. capuroniana De Block-Madagascar, Bremer et al. 5041 (S),

698 KJ815386, KJ815634; T. depauperata Hutch._China, Chow \& Wan 79063 (UPS), KM592256,

699 KM592162; T. flava Alston-Sri Lanka, Klackenberg 440 (S), KM592257, KM592163; $\boldsymbol{T}$.

700 fuscoflava (K.Schum.) S.Moore-Ghana, Schmidt et al. 2099 (MO), KM592258, KM592164; $\boldsymbol{T}$.

701 gracilipes (Hayata) Ohwi-Japan, Van Caekenberghe 149 (BR), KM592259, KM592165; $\boldsymbol{T}$.

702 grevei (Drake) Homolle-Madagascar, De Block et al. 959 (BR), KM592274, KM592180; $\boldsymbol{T}$.

703 jolinonii N.Hallé-Gabon, Champluvier 6098 (BR), KM592260, KM592166; T. lasiorachis

704 (K.Schum. \& K.Krause) Bremek.-Gabon, Wieringa 4432 (WAG), KM592261, KM592167; $\boldsymbol{T}$.

705 leioloba (Guillaumin) S.Moore-New Caledonia, Mouly 174 (P), KM592262, KM592168; $\boldsymbol{T}$.

706 microcarpa (Guillaumin) Jérémie-New Caledonia, Mouly 297 (P), KM592263, KM592169; $\boldsymbol{T}$.

707 nitidula (Benth.) Hiern-Liberia, Jongkind 8000 (BR), KM592264, KM592170; T. pallidula

708 Hiern-Gabon, Dessein et al. 2215 (BR), KM592265, KM592171; T. pembensis J.E.Burrows- 
709 Mozambique, Luke et al. 10136 (UPS), KM592266, KM592172; T. precidantenna N.Hallé-

710 Gabon, Dessein et al. 2360 (BR), KM592267, KM592173; T. rhypalostigma (Schltr.) Bremek.-

711 New Caledonia, Mouly 182 (P), KM592268, KM592174; T. roseicosta Bridson-Tanzania,

712 Luke et al. 9170 (UPS), KM592269, KM592175; T. sambucina (G.Forst.) T.Durand ex Drake-

713 New Caledonia, Mouly et al. 364 (P), KM592270, KM592176; T. spiranthera (Drake)

714 Homolle-Madagascar, De Block et al. 946 (BR), KM592275, KM592181; T. thouarsiana

715 (Drake) Homolle-Madagascar, De Block et al. 655 (BR), KM592276, KM592182; T. uniflora

716 (Drake) Homolle-Madagascar, Bremer et al. 5230 (S), KM592277, KM592183; T. vignei Hutch.

717 \& Dalziel-Republic of Guinea, Jongkind 8126 (BR), KM592271, KM592177.

718 Tennantia sennii (Chiov.) Verdc. \& Bridson-Kenya, Luke et al. 8357 (UPS),

719 KM592278, KM592184.

720 Tribe Vanguerieae: Vangueria madagascariensis J.F.Gmel.-Africa (country

721 unknown), Delprete 7383 (NY), EU821636, - .

722

723 REFERENCES

724 Adam JG. 1974. Un Clerodendrum nouveau pour la Guinée, Clerodendrum sylviae J.G. Adam. 725 Adansonia sér. 2,14(2):303 - 306.

726

727

728

729

730

731

Anderson S. 2002. Identifying Important Plant Areas: a site selection manual for Europe. Salisbury: Plantlife International. Available at www.plantlife.org.uk/publications/identifying important plant areas a site selection manual for europe (accessed 20 November 2017).

Bachman S, Fernandez EP, Hargreaves S, Nic Lughadha E, Rivers M, Williams E. 2016. Extinction risk and threats to plants. In: State of the World's Plants Report 2016. Kew: 

(accessed 20 November 2017).

734

Bachman S, Moat J, Hill AW, de la Torre J, Scott B. 2011. Supporting Red List threat assessments with GeoCAT: geospatial conservation assessment tool, in: Smith V, Penev L, eds. e-Infrastructures for data publishing in biodiversity science. ZooKeys 150:117126. Available at http://geocat.kew.org/ (accessed 20 November 2017).

Boar RB, Roner RC. 1975. Cycloartane triterpenoids. Phytochem. 14 (5-6): 1143-1146.

Bridson D, Forman L. 1998. The Herbarium Handbook. $3^{\text {rd }}$ Ed. Kew: Royal Botanic Gardens. Bridson D, Verdcourt B. 1988. Rubiaceae (Part 2). Flora of Tropical East Africa. Rotterdam: Balkema.

Brummitt NA, Bachman SP, Griffiths-Lee J, Lutz M, Moat JF, Farjon A, Donaldson JS, Hilton-Taylor C, Meagher TR, Albuquerque S, Aletrari E, Andrews AK, Atchison G, Baloch E, Barlozzini B, Brunazzi A, Carretero J, Celesti M, Chadburn H, Cianfoni E, Cockel C, Coldwell V, Concetti B, Contu S, Crook V, Dyson P, Gardiner L, Ghanim N, Greene H, Groom A, Harker R, Hopkins D, Khela S, LakemanFraser P, Lindon H, Lockwood H, Loftus C, Lombrici D, Lopez-Poveda L, Lyon J, Malcolm-Tompkins P, McGregor K, Moreno L, Murray L, Nazar K, Power E, Quiton Tuijtelaars M, Salter R, Segrott R, Thacker H, Thomas LJ, Tingvoll S, Watkinson G, Wojtaszekova K, Nic Lughadha EM. 2015. Green plants in the red: a baseline global assessment for the IUCN Sampled Red List Index for Plants. PLOS ONE 10(8):e0135152 DOI 10.1371/journal.pone.0135152.

Brunel JF. 1987. Sur le genre Phyllanthus L. et quelques genres voisins de la tribu des Phyllantheae Dumort. (Euphorbiaceae-Phyllantheae) en Afrique Intertropicale et à 
Madagascar. PhD thesis. Strasbourg: Université Louis Pasteur.

756

757

758

759

760

761

762

763

764

765

766

767

768

769

770

771

772

773

774

775

776

777

CCD. 2017. Combined Chemical Dictionary Online (CCD 21.1) Taylor \& Francis Group. Available at http://ccd.chemnetbase.com/dictionary (accessed 17 November 2017).

Champluvier D, Darbyshire I. 2009. A revision of the genera Brachystephanus and Oreacanthus (Acanthaceae) in tropical Africa. Systematics \& Geography of Plants 79: 115-192. DOI 10.2307/25746605.

Cheek M. 2009. Mussaenda epiphytica sp. nov. (Rubiaceae), an epiphytic shrub from cloud forest of the Bakossi Mts, Western Cameroon. Nordic Journal of Botany 27:456-459 DOI 10.1111/j.1756-1051.2009.00576.x.

Cheek M, Ameka G. 2016. Macropodiella cussetiana (Podostemaceae) a new species from Côte d'Ivoire. Kew Bulletin 17: 21. DOI 10.1007/S12225-016-9634-9.

Cheek M, Challen G, Lebbie A, Banks H, Barberá P, Riina R. 2016. Discovering Karima (Euphorbiaceae) a new Crotonoid genus from West Tropical Africa long hidden within Croton. PLOS ONE 11(4):e0152110 DOI 10.1371/journal.pone.0152110.

Cheek M, Challen G, Merklinger F, Molmou D. 2013. Breynia disticha, a new invasive alien for Tropical Africa. Aliens 33:32-34. http://www.issg.org/pdf/aliens_newsletters/A33.pdf.

Cheek M, Luke Q. 2016. Calophyllum (Clusiaceae - Guttiferae) in Africa. Kew Bulletin 71:20. DOI 10.1007/S12225-016-9637-6.

Cheek M, van der Burgt X. 2010. Gymnosiphon samoritoureanus (Burmanniaceae) a new species from Guinea, with new records of other achlorophyllous heteromycotrophs. Kew Bulletin 65:83-88 DOI 10.1007/s12225-010-9180-9.

Cheek M, Williams T. 2016. Psychotria samoritourei (Rubiaceae), a new liana species from Loma-Man in Upper Guinea, West Africa. Kew Bulletin 71: in press. DOI 
779

780

781

782

783

784

785

Corlett RT. 2016. Plant diversity in a changing world: status, trends, and conservation needs. Plant Diversity 38:10-16 DOI 10.1016/j.pld.2016.01.001.

\section{Couch C, Molmou D, Camara B, Cheek M, Merklinger F, Davies L, Harvey Y, Lopez} Poveda L, Redstone S. 2014. Conservation of threatened Guinean inselberg species. Abstracts of the XX ${ }^{\text {th }}$ AETFAT Congress, South Africa, 2014. Scripta Botanica Belgica 52:96.

Darbyshire I. continuously updated. Tropical Important Plant Areas. Available at http://science.kew.org/strategic-output/tropical-important-plant-areas (accessed 20 November 2017).

Darbyshire I, Pearce L, Banks H. 2012. The genus Isoglossa (Acanthaceae) in West Africa. Kew Bulletin 66:425-439 DOI 10.1007/s12225-011-9292-x.

Darbyshire I, Anderson S, Asatryan A, Byfield A, Cheek M, Clubbe C, Ghrabi Z, Harris T, Heatubun CD, Kalema J, Magassouba S, McCarthy B, Milliken W, de Montmollin B, Nic Lughadha E, Onana JM, Doumbouya S, Sârbu A, Shrestha K, Radford EA. 2017. Important Plant Areas: revised selection criteria for a global approach to plant conservation. Biodiversity and Conservation 26:1767-1800 DOI 10.1007/s10531-017$\underline{1336-6 .}$

Davis PH, Heywood VH. 1963. Principles of Angiosperm Taxonomy. Princeton: Van Nostrand.

De Block P. 2003. Robbrechtia, a new Rubiaceae genus from Madagascar. Systematic Botany 28: 145-156. https://www.jstor.org/stable/3093944

De Block P, Robbrecht E. 1998. Pollen morphology of the Pavetteae (Rubiaceae, Ixoroideae) and its taxonomic significance. Grana 37:260-275. DOI 10.1080/00173139809362678. 
801 De Block P, Razafimandimbison SG, Janssens S, Ochoterena H, Robbrecht E, Bremer B.

802 2015. Molecular phylogenetics and generic assessment in the tribe Pavetteae (Rubiaceae).

803 Taxon 64(1):79-95 DOI 10.12705/641.19.

804 Fischer E, Darbyshire I, Cheek M. 2011. Striga magnibracteata (Orobanchaceae) a new

805 species from Guinée and Mali. Kew Bulletin 66:441-445. DOI 10.1007/s12225-011-

806 $\underline{9296-6}$

807 Goyder DJ. 2009. Xysmalobium samoritourei (Apocynaceae: Asclepiadoideae), a new species 808 from the Guinea Highlands of West Africa. Kew Bulletin 63:473 - 475 DOI:

809 $\underline{10.1007 / \mathrm{s} 12225-008-9059-1 .}$.

810 Hallé N. 1970. Famille des Rubiacées (2 parts). Flore du Gabon 17. Paris.

811 Harvey Y, Baena S, Williams T, Cisse S, Pearce L, van der Burgt X, Cheek M. 2010.

812 Guinea-Conakry: New Discoveries in the Simandou Range. In: van der Burgt X et al., eds.

813 Proceedings of the 2007 AETFAT Congress. Kew: Royal Botanic Gardens.

814 Hepper FN, Keay RWJ. 1963. Rubiaceae. Key to the Tribes. In: Hepper FN, ed. Flora of West 815 Tropical Africa. $2^{\text {nd }}$ Ed. Vol. 2. London: Crown Agents, 104.

816 Herbier National de Guinée. 2017. Zones Importantes des Plantes. Available at 817 http://www.herbierguinee.org/ztips-darwin.html (accessed 21 November 2017).

818 Hill RA, Connolly JD. 2017. Triterpenoids. Natural Product Reports 34:90-122.

819 Howes M-JR. 2018. Phytochemicals as anti-inflammatory nutraceuticals and 820 phytopharmaceuticals. In: Chatterjee S, Jungraithmayr W, Bagchi D, eds. Immunity and 821 Inflammation in Health and Disease. Emerging Roles of Nutraceuticals and Functional 822 Foods in Immune Support. Academic Press (Elsevier), 363-388.

823 IPNI. continuously updated. The International Plant Names Index. Available at 

http://www.ipni.org/ (accessed 20 November 2017.

825 IUCN. 2012. IUCN Red List Categories and Criteria: Version 3.1. Second edition. Gland, 826 Switzerland and Cambridge UK: IUCN.

827 Katoh K, Asimenos G, Toh H. 2009. Multiple alignment of DNA sequences with MAFFT. 828 Methods in Molecular Biology 537:39-64.

829 Katoh K, Standley DM. 2013. MAFFT multiple sequence alignment software version 7: improvements in performance and usability. Molecular Biology and Evolution 30:772780.

Kearse M, Moir R, Wilson A, Stones-Haves S, Cheung M, Sturrock S, Buxton S, Cooper A, Markowitz S, Duran C, Thierer T, Ashton B, Meintjes P, Drummond A. 2012. Geneious Basic: an integrated and extendable desktop software platform for the organization and analysis of sequence data. Bioinformatics 28:1647-1649. Gardenia gummifera and Gardenia lucida. Chem. Biodivers. 6(8): 1185-1192. (Rubiaceae) and range extensions for some rare species. Pl. Ecol. Evol. 146: 121-133. DOI: $10.5091 /$ plecevo.2013.632.

843 Larridon I, Couch C. 2016. Training the trainers in Guinea. Available at https://www.kew.org/blogs/kew-science/training-trainers-guinea (accessed 21 November 2017).

Lisowski S. 2009. Flore (angiospermes) de la République de Guinée. Scripta Botanica Belgica 
volumes $41 \& 42$. Meise: National Botanic Garden of Belgium.

848

849

850

851

852

853

854

855

856

857

858

Magassouba S, Camara B, Guilovogui K, Cheek M, Couch C, Lopez Poveda L, van der Burgt X, Bachman S, Harvey Y. 2014. Hunting Threatened taxa of Guinea. Abstracts of the $X^{\text {th }}$ AETFAT Congress, South Africa, 2014. Scripta Botanica Belgica 52:255.

Miller MA, Pfeiffer W, Schwartz T. 2010. Creating the CIPRES Science Gateway for Inference of Large Phylogenetic Trees. 14 November 2010, New Orleans, LA, 1-8.

Müller J, Müller K, Neinhuis C, Quandt D. 2010. PhyDE-Phylogenetic Data Editor, version 0.9971. Available at http://www.phyde.de/ (accessed 10 January 2016).

Nes WD, Heftmann E. 1981. A comparison of triterpenoids with steroids as membrane components. J. Nat. Prod. 44(4): 377-400.

Neuba DFR, Malan DF, Kouadio YL. 2014. Notes sur le genre Africain Leptactina Hook.f. (Rubiaceae, Pavetteae). Adansonia sér. 3,36(1):121-153. DOI 10.5252/a2014n1a11.

Onana J-M, Cheek M. 2011. Red Data Book of the Flowering Plants of Cameroon: IUCN Global Assessments. Kew: Royal Botanic Gardens.

Phillips SM, Mesterházy A. 2015. Revision of small ephemeral species of Eriocaulon (Eriocaulaceae) in West Africa with long involucral bracts. Kew Bulletin 70:5. DOI $\underline{10.1007 / \mathrm{s} 12225-014-9557-2 .}$

Plantlife International. 2004. Identifying and protecting the world's most Important Plant Areas. Salisbury: Plantlife International. Available at www.plantlife.org.uk/publications/identifying and protecting the worlds most importa nt_plant_areas (accessed 20 November 2017).

Porembski S, Barthlott W. 1999. Pitcairnia feliciana: the only indigenous African bromeliad. Harvard Papers in Botany 4(1): 175-184. https://www.jstor.org/stable/41761298 
870 Prance GT, Jongkind CCH. 2015. A revision of African Lecythidaceae. Kew Bulletin 70:6.

$871 \quad$ DOI 10.1007/s12225-014-9547-4.

872 Puff C, Robbrecht E, Buchner R, De Block P. 1996. Survey of secondary pollen presentation 873 in the Rubiaceae. Proceedings of the second international Rubiaceae conference. Opera Botanica Belgica 7: 369-402.

Rambaut A. 2016. FigTree version 1.4.3. Available at http://tree.bio.ed.ac.uk/software/figtree/ (accessed 10 January 2017).

Rambaut A, Suchard MA, Xie D, Drummond AJ. 2014. Tracer, version 1.6 [online computer program]. Available at http://beast.bio.ed.ac.uk/Tracer/ (accessed 10 January 2016).

Rhourrhi-Frih B, West C, Pasquier L, André P, Chaimbault P, Lafosse M. 2012. $177-190$.

Robbrecht, E. 1988. Tropical woody Rubiaceae: Characteristic features and progressions; Contributions to a new subfamilial classification. Opera Botanica Belgica 1:1-271.

Ronquist F, Teslenko M, van der Mark P, Ayres DL, Darling A, Hohna S, Larget B, Liu L,

Schymanski EL, Jeon J, Gulde R, Fenner K, Ruff M, Singer HP, Hollender J. 2014. confidence. Environ. Sci. Technol. 48: 2097-2098. DOI 10.1021/es5002105

892 Shorthouse, David P. 2010. SimpleMappr, an online tool to produce publication-quality point 

maps. Available at http://www.simplemappr.net (accessed 22 November 2017).

894 Stamatakis, A., 2014. RAxML Version 8: A tool for phylogenetic analysis and post-analysis of 895 large phylogenies. Bioinformatics 30:1312-1313. DOI 10.1093/bioinformatics/btu033.

896 Stöver, B.C., Müller, K.F., 2010. TreeGraph 2: Combining and visualizing evidence from different phylogenetic analyses. BMC Bioinformatics 11:7 DOI 10.1186/1471-2105-11-7.

Sosef MS, Dauby G, Blach-Overgaard A, van der Burgt X, Catarino L, Damen T, Deblauwe V, Dessein S, Dransfield J, Droissart V, Duarte MC, Engledow H, Fadeur G, Figuira R, Gereau RE, Hardy OJ, Harris DJ, de Heij J, Janssens S, Klomberg Y,

901 Ley AC, Mackinder BA, Meerts P, van de Poel JL, Sonké B, Stévart T, Stoffelen P, Svenning JC, Sepulchre P, Zaiss R, Wieringa JJ, Couvreur TLP. 2017. Exploring the floristic diversity of tropical Africa. BMC Biology 15:15 DOI 10.1186/s12915-017-0356$\underline{8}$.

Thiers B. continuously updated. Index Herbariorum. Available at http://sweetgum.nybg.org/science/ih/ (accessed 20 November 2017). 


\section{Table $\mathbf{1}$ (on next page)}

Characters separating Kindia from Leptactina s.l., including Coleactina and Dictyandra (i.e. the remainder of Pavetteae Clade II according to De Block et al., 2015).

Data for Leptactina morphology were taken from specimen measurements and from Hallé (1970) and Neuba et al. (2014). Data for the pollen characters of Leptactina are based on De Block \& Robbrecht (1998). 
1 Table 1. Characters separating Kindia from Leptactina s.l., including Coleactina and Dictyandra (i.e. the remainder of Pavetteae

2 Clade II according to De Block et al., 2015). Data for Leptactina morphology were taken from specimen measurements and from

3 Hallé (1970) and Neuba et al. (2014). Data for the pollen characters of Leptactina are based on De Block \& Robbrecht (1998).

\begin{tabular}{|c|c|c|}
\hline Characters & Leptactina s.l. & Kindia \\
\hline Pollen: apocolpial index & $0.39-0.68$ & 0.125 \\
\hline Pollen aperture number & $(3-) 4$ & 3 \\
\hline Anther attachment & $\begin{array}{l}\text { Sub-apical or medifixed (except sub- } \\
\text { basal in L. arborescens) }\end{array}$ & Sub-basal \\
\hline Anther apical connective appendage & Present & Absent \\
\hline Style arms at anthesis & Divergent (except L. pynaertii) & Appressed together \\
\hline Corolla tube shape & $\begin{array}{l}\text { long narrow cylindrical sometimes } \\
\text { widening subtly at the throat (where } \\
\text { anthers are included) }\end{array}$ & $\begin{array}{l}\text { Strongly infundibular-campanulate, } \\
\text { short proximal narrow section abruptly } \\
\text { widening to long, broad distal section }\end{array}$ \\
\hline $\begin{array}{l}\text { Presence of a dense, discrete band of hairs near } \\
\text { base of corolla tube }\end{array}$ & Absent & Present \\
\hline Pollen presenter & Smooth, usually hairy & Longitudinally winged, glabrous \\
\hline Colleter exudate from apical bud & $\begin{array}{l}\text { Usually not conspicuous; if } \\
\text { conspicuous, translucent, colourless }\end{array}$ & Conspicuous, opaque, bright red \\
\hline
\end{tabular}




\section{Table 2 (on next page)}

Compounds assigned from LC-MS/MS analysis (negative mode) of the colleter exudate from Cheek 18345. 
1 Table 2. Compounds assigned from LC-MS/MS analysis (negative mode) of the colleter exudate from Cheek 18345.

\begin{tabular}{|c|c|c|c|c|c|}
\hline Assigned compound ${ }^{\#}$ (or isomer) & $\begin{array}{l}\text { Retention time } \\
\text { (min) }\end{array}$ & Molecular formula & $(m / z)$ & Ion & $\mathbf{p p m}^{\#}$ \\
\hline Trihydroxy-oxocycloartanoic acid & 12.3 & $\mathrm{C}_{30} \mathrm{H}_{48} \mathrm{O}_{6}$ & 503.3385 & {$[\mathrm{M}-\mathrm{H}]^{-}$} & 1.366 \\
\hline Pentahydroxy-(hydroxylmethyl) cycloartanoic acid & 12.4 & $\mathrm{C}_{31} \mathrm{H}_{52} \mathrm{O}_{8}$ & 551.3596 & {$[\mathrm{M}-\mathrm{H}]^{-}$} & 1.230 \\
\hline Epoxy-trihydroxy-cycloartenoic acid & 12.9 & $\mathrm{C}_{30} \mathrm{H}_{46} \mathrm{O}_{6}$ & 501.3228 & {$[\mathrm{M}-\mathrm{H}]^{-}$} & 1.112 \\
\hline Epoxy-trihydroxy-cycloartenoic acid & 13.0 & $\mathrm{C}_{30} \mathrm{H}_{46} \mathrm{O}_{6}$ & 501.3225 & {$[\mathrm{M}-\mathrm{H}]^{-}$} & 0.993 \\
\hline Epoxy-trihydroxy-cycloartenoic acid & 13.2 & $\mathrm{C}_{30} \mathrm{H}_{46} \mathrm{O}_{6}$ & 501.3231 & {$[\mathrm{M}-\mathrm{H}]^{-}$} & 1.910 \\
\hline Epoxy-trihydroxy-cycloartenoic acid & 13.3 & $\mathrm{C}_{30} \mathrm{H}_{46} \mathrm{O}_{6}$ & 501.3229 & {$[\mathrm{M}-\mathrm{H}]^{-}$} & 1.372 \\
\hline Trihydroxy-oxocycloartanoic acid & 13.8 & $\mathrm{C}_{30} \mathrm{H}_{48} \mathrm{O}_{6}$ & 503.3379 & {$[\mathrm{M}-\mathrm{H}]^{-}$} & 0.154 \\
\hline Trihydroxy-oxocycloartanoic acid & 14.0 & $\mathrm{C}_{30} \mathrm{H}_{48} \mathrm{O}_{6}$ & 503.3380 & {$[\mathrm{M}-\mathrm{H}]^{-}$} & 0.273 \\
\hline Dikamaliartane $\mathrm{A}^{\mathrm{a}}$ & 14.3 & $\mathrm{C}_{30} \mathrm{H}_{44} \mathrm{O}_{6}$ & 499.3068 & {$[\mathrm{M}-\mathrm{H}]^{-}$} & 0.556 \\
\hline Trihydroxy-oxocycloartanoic acid & 14.6 & $\mathrm{C}_{30} \mathrm{H}_{48} \mathrm{O}_{6}$ & 503.3384 & {$[\mathrm{M}-\mathrm{H}]^{-}$} & 1.247 \\
\hline $\begin{array}{l}\text { 1,3-Dihydroxy-23-oxocycloartan-28-oic acid (= carinatin } \\
\text { A) }{ }^{\mathrm{b}} \text { or 4,28-dihydroxy-26-oxo-3,4-secocycloart-24-en-3- } \\
\text { oic acid (= gardenoin J) }\end{array}$ & 15.0 & $\mathrm{C}_{30} \mathrm{H}_{48} \mathrm{O}_{5}$ & 487.3435 & {$[\mathrm{M}-\mathrm{H}]^{-}$} & 1.195 \\
\hline $\begin{array}{l}\text { 1,3-Dihydroxy-23-oxocycloartan-28-oic acid (= carinatin } \\
\text { A) or } 4,28 \text {-dihydroxy-26-oxo-3,4-secocycloart-24-en-3- } \\
\text { oic acid }(=\text { gardenoin J) }\end{array}$ & 15.9 & $\mathrm{C}_{30} \mathrm{H}_{48} \mathrm{O}_{5}$ & 487.3433 & {$[\mathrm{M}-\mathrm{H}]^{-}$} & 0.743 \\
\hline $\begin{array}{l}\text { 1,3-Dihydroxy-23-oxocycloartan-28-oic acid (= carinatin } \\
\text { A) or } 4,28 \text {-dihydroxy-26-oxo-3,4-secocycloart-24-en-3- } \\
\text { oic acid (= gardenoin J) }\end{array}$ & 16.3 & $\mathrm{C}_{30} \mathrm{H}_{48} \mathrm{O}_{5}$ & 487.3432 & {$[\mathrm{M}-\mathrm{H}]^{-}$} & 0.559 \\
\hline $\begin{array}{l}\text { 1,3-Dihydroxy-23-oxocycloart-24-en-28-oic acid (= } \\
\text { gardenolic acid B) }^{\mathrm{d}}\end{array}$ & 16.5 & $\mathrm{C}_{30} \mathrm{H}_{46} \mathrm{O}_{5}$ & 485.3274 & {$[\mathrm{M}-\mathrm{H}]^{-}$} & 0.355 \\
\hline $\begin{array}{l}\text { 1,3-Dihydroxy-23-oxocycloartan-28-oic acid (= carinatin } \\
\text { A) })^{\mathrm{b}} \text { or } 4,28 \text {-dihydroxy-26-oxo-3,4-secocycloart-24-en-3- } \\
\text { oic acid }(=\text { gardenoin J })^{\mathrm{c}}\end{array}$ & 16.6 & $\mathrm{C}_{30} \mathrm{H}_{48} \mathrm{O}_{5}$ & 487.3432 & {$[\mathrm{M}-\mathrm{H}]^{-}$} & 0.682 \\
\hline $\begin{array}{l}\text { 1,3-Dihydroxy-23-oxocycloart-24-en-28-oic acid (= } \\
\text { gardenolic acid B) }\end{array}$ & 17.3 & $\mathrm{C}_{30} \mathrm{H}_{46} \mathrm{O}_{5}$ & 485.3276 & {$[\mathrm{M}-\mathrm{H}]^{-}$} & 0.746 \\
\hline $\begin{array}{l}\text { 1,3-Dihydroxy-23-oxocycloart-24-en-28-oic acid (= } \\
\text { gardenolic acid B) }\end{array}$ & 17.5 & $\mathrm{C}_{30} \mathrm{H}_{46} \mathrm{O}_{5}$ & 485.3272 & {$[\mathrm{M}-\mathrm{H}]^{-}$} & 0.016 \\
\hline $\begin{array}{l}\text { 1,3-Dihydroxy-23-oxocycloart-24-en-28-oic acid (= } \\
\text { gardenolic acid B) }\end{array}$ & 17.8 & $\mathrm{C}_{30} \mathrm{H}_{46} \mathrm{O}_{5}$ & 485.3280 & {$[\mathrm{M}-\mathrm{H}]^{-}$} & 1.550 \\
\hline Epoxy-trihydroxy-cycloartenoic acid & 18.2 & $\mathrm{C}_{30} \mathrm{H}_{46} \mathrm{O}_{6}$ & 501.3228 & {$[\mathrm{M}-\mathrm{H}]^{-}$} & 1.292 \\
\hline 1,3-Dihydroxy-23-oxocycloart-24-en-28-oic acid (= & 19.4 & $\mathrm{C}_{30} \mathrm{H}_{46} \mathrm{O}_{5}$ & 485.3279 & {$[\mathrm{M}-\mathrm{H}]^{-}$} & 1.303 \\
\hline
\end{tabular}


gardenolic acid $\mathrm{B})^{\mathrm{d}}$

1,3-Dihydroxy-23-oxocycloartan-28-oic acid (= carinatin A) ${ }^{b}$ or 4,28-dihydroxy-26-oxo-3,4-secocycloart-24-en-3oic acid (= gardenoin $\mathrm{J})^{\mathrm{c}}$

1,3-Dihydroxy-23-oxocycloart-24-en-28-oic acid (= gardenolic acid $\mathrm{B})^{\mathrm{d}}$

1,3-Dihydroxy-23-oxocycloartan-28-oic acid (= carinatin A) ${ }^{b}$ or 4,28-gihydroxy-26-oxo-3,4-secocycloart-24-en-3oic acid (= gardenoin $\mathrm{J})^{\mathrm{c}}$

Gummiferartane $3^{\mathrm{e}}$

1,2,3,4-Octadecanetetrol; 1-O- rhamnoside $^{\mathrm{f}}$

7-Hydroxy-3,4-secocycloarta-4(28),24-diene-3,26-dioic acid; 3-Me ester or 4-hydroxy-3,4-secocycloart-24-en-

26,22-olid-3-oic acid; Me ester

23,26-Epoxy-6,28-dihydroxy-3,4-secocycloarta-

4(29),23,25-trien-3-oic acidg

$1,2,3,4-$ Eicosanetetrol $^{\mathrm{h}}$

19.5

19.9

20.3

20.8

20.9

21.0

21.2

21.6

Gummiferartane $3^{\mathrm{e}}$

1,3-Dihydroxy-23-oxocycloartan-28-oic acid (= carinatin

A) ${ }^{b}$ or 4,28-dihydroxy-26-oxo-3,4-secocycloart-24-en-3oic acid (= gardenoin $\mathrm{J})^{\mathrm{c}}$

1,2,3,4-Octadecanetetrol; $1-O$ - rhamnoside $^{\mathrm{f}}$

1,2,3,4-Octadecanetetrol; $1-O$ - rhamnoside ${ }^{\mathrm{f}}$

1,3-Dihydroxy-23-oxocycloartan-28-oic acid (= carinatin

A) ${ }^{b}$ or 4,28-dihydroxy-26-oxo-3,4-secocycloart-24-en-3oic acid (= gardenoin $\mathrm{J})^{\mathrm{c}}$

Dihydroxy-methoxycycloartenoic acid or diepoxy-

methoxycycloartane-diol

1,3-Dihydroxy-23-oxocycloart-24-en-28-oic acid (= gardenolic acid B) ${ }^{\mathrm{d}}$

Dikamaliartane $\mathrm{D}^{\mathrm{a}}$ or $\mathrm{F}^{\mathrm{a}}$

Gummiferartane $4^{\mathrm{e}}$ or $9^{\mathrm{e}}$

1,3-Dihydroxy-23-oxocycloart-24-en-28-oic acid (= gardenolic acid $\mathrm{B})^{\mathrm{d}}$

Gummiferartane $4^{\mathrm{e}}$ or $9^{\mathrm{e}}$

23.6

23.8
$\mathrm{C}_{30} \mathrm{H}_{48} \mathrm{O}_{5}$

487.3432

$[\mathrm{M}-\mathrm{H}]^{-}$

0.682

$\mathrm{C}_{30} \mathrm{H}_{46} \mathrm{O}_{5}$

485.3272

$[\mathrm{M}-\mathrm{H}]^{-}$

0.016

$\mathrm{C}_{30} \mathrm{H}_{48} \mathrm{O}_{5}$

487.3434

$[\mathrm{M}-\mathrm{H}]$

0.928

$\mathrm{C}_{30} \mathrm{H}_{50} \mathrm{O}_{5}$

$\mathrm{C}_{24} \mathrm{H}_{48} \mathrm{O}_{8}$

$\mathrm{C}_{31} \mathrm{H}_{48} \mathrm{O}_{5}$

489.3549

463.3281

499.3435

$[\mathrm{M}-\mathrm{H}]^{-}$

$[\mathrm{M}-\mathrm{H}]^{-}$

$[\mathrm{M}-\mathrm{H}]^{-}$

0.638

0.903

1.166

$\mathrm{C}_{30} \mathrm{H}_{44} \mathrm{O}_{5}$

$483.3124 \quad[\mathrm{M}-\mathrm{H}]^{-}$

1.619

391.3069

$\mathrm{C}_{20} \mathrm{H}_{42} \mathrm{O}_{4}$

$\mathrm{C}_{30} \mathrm{H}_{50} \mathrm{O}_{5}$

$\mathrm{C}_{30} \mathrm{H}_{48} \mathrm{O}_{5}$

489.3590

487.3433

$[\mathrm{M}+$

$\mathrm{HCOO}^{-}$

$[\mathrm{M}-\mathrm{H}]^{-}$

$[\mathrm{M}-\mathrm{H}]^{-}$

$\mathrm{C}_{24} \mathrm{H}_{48} \mathrm{O}_{8}$

$\mathrm{C}_{24} \mathrm{H}_{48} \mathrm{O}_{8}$

$\mathrm{C}_{30} \mathrm{H}_{48} \mathrm{O}_{5}$

463.3283

463.3283

$[\mathrm{M}-\mathrm{H}]$

$[\mathrm{M}-\mathrm{H}]$

$[\mathrm{M}-\mathrm{H}]^{-}$

.378

487.3435

$\mathrm{C}_{31} \mathrm{H}_{50} \mathrm{O}_{5}$

501.3589

[M - H]

0.682

$\mathrm{C}_{30} \mathrm{H}_{46} \mathrm{O}_{5}$

485.3278

$[\mathrm{M}-\mathrm{H}]$

1.179

$\mathrm{C}_{30} \mathrm{H}_{46} \mathrm{O}_{4}$

469.2968

$[\mathrm{M}-\mathrm{H}]$

$[\mathrm{M}-\mathrm{H}]$

1.314

$\mathrm{C}_{30} \mathrm{H}_{48} \mathrm{O}_{4}$

471.3483

485.3283

$[\mathrm{M}-\mathrm{H}]$

2.251

$\mathrm{C}_{30} \mathrm{H}_{48} \mathrm{O}_{4}$

471.3483

0.608 
Dikamaliartane $\mathrm{D}^{\mathrm{a}}$ or $\mathrm{F}$

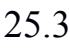

Gummiferartane $4^{\mathrm{e}}$ or $9^{\mathrm{e}}$

Dikamaliartane $\mathrm{D}^{\mathrm{a}}$ or $\mathrm{F}^{\mathrm{a}}$

6,25-Dihydroxy-29-nor-3,4-secocycloarta-4(28),23-dien-

3-oic acid; 25-Me ether, Me ester ${ }^{\mathrm{i}}$ or dihydroxy-

methylenecycloartanoic acid

Dikamaliartane $\mathrm{D}^{\mathrm{a}}$ or $\mathrm{F}^{\mathrm{a}}$

Gummiferartane $4^{\mathrm{e}}$ or $9^{\mathrm{e}}$

25.7

25.9
26.9

27.8

$$
\begin{aligned}
& \mathrm{C}_{30} \mathrm{H}_{46} \mathrm{O}_{4} \\
& \mathrm{C}_{30} \mathrm{H}_{48} \mathrm{O}_{4} \\
& \mathrm{C}_{30} \mathrm{H}_{46} \mathrm{O}_{4} \\
& \mathrm{C}_{31} \mathrm{H}_{50} \mathrm{O}_{4}
\end{aligned}
$$

$\mathrm{C}_{30} \mathrm{H}_{46} \mathrm{O}_{4}$

$\mathrm{C}_{30} \mathrm{H}_{48} \mathrm{O}_{4}$
469.3328

471.3489

939.67328

485.3647

[M - H]

[M - H]

$[2 \mathrm{M}-\mathrm{H}]$

$[\mathrm{M}-\mathrm{H}]^{-}$

0.973

1.966

423

.177

${ }^{a}$ Reported to occur in Gardenia gummifera L.f. and G. lucida Roxb. (Kunert et al., 2009); the latter a synonym for G. resinifera Roth.

Occurs in Gardenia carinata Wall. ex Roxb. (CCD, 2017).

'Occurs in Gardenia thailandica Tirveng. (CCD, 2017).

${ }^{\mathrm{d} O c c u r s ~ i n ~ G a r d e n i a ~ j a s m i n o i d e s ~ J . E l l i s ~(C C D, ~ 2017) . ~}$

'Occurs in Gardenia gummifera $(C C D, 2017)$.

${ }^{\mathrm{f}}$ Constituent of the resin of Commiphora opobalsamum (L.) Engl. (CCD, 2017); synonym for Commiphora gileadensis (L.) C.Chr. gOccurs in Gardenia obtusifolia Roxb. ex Hook.f. (CCD, 2017).

${ }^{\mathrm{h} D}$-xylo-form (guggultetrol 20) occurs in Commiphora mukul (Hook. ex Stocks) Engl. resin (CCD, 2017).

iOccurs in Antirhea acutata (DC.) Urb. (CCD, 2017); synonym for Stenostomum acutatum DC. 


\section{Figure 1}

Photographs showing the cliff-dwelling habitat and the habit of Kindia gangan at Mt Gangan, Kindia, Guinea.

(A) plants scattered on high sandstone cliff (Cheek 18345); (B) plant habit on cliff face (Cheek 18541A); C frontal view of flower (Cheek 18541A); (D) side view of inflorescence showing cupular bract (Cheek 18541A); (E) opened fruit showing ripe seeds (Cheek 18345). Photos taken by Martin Cheek. 


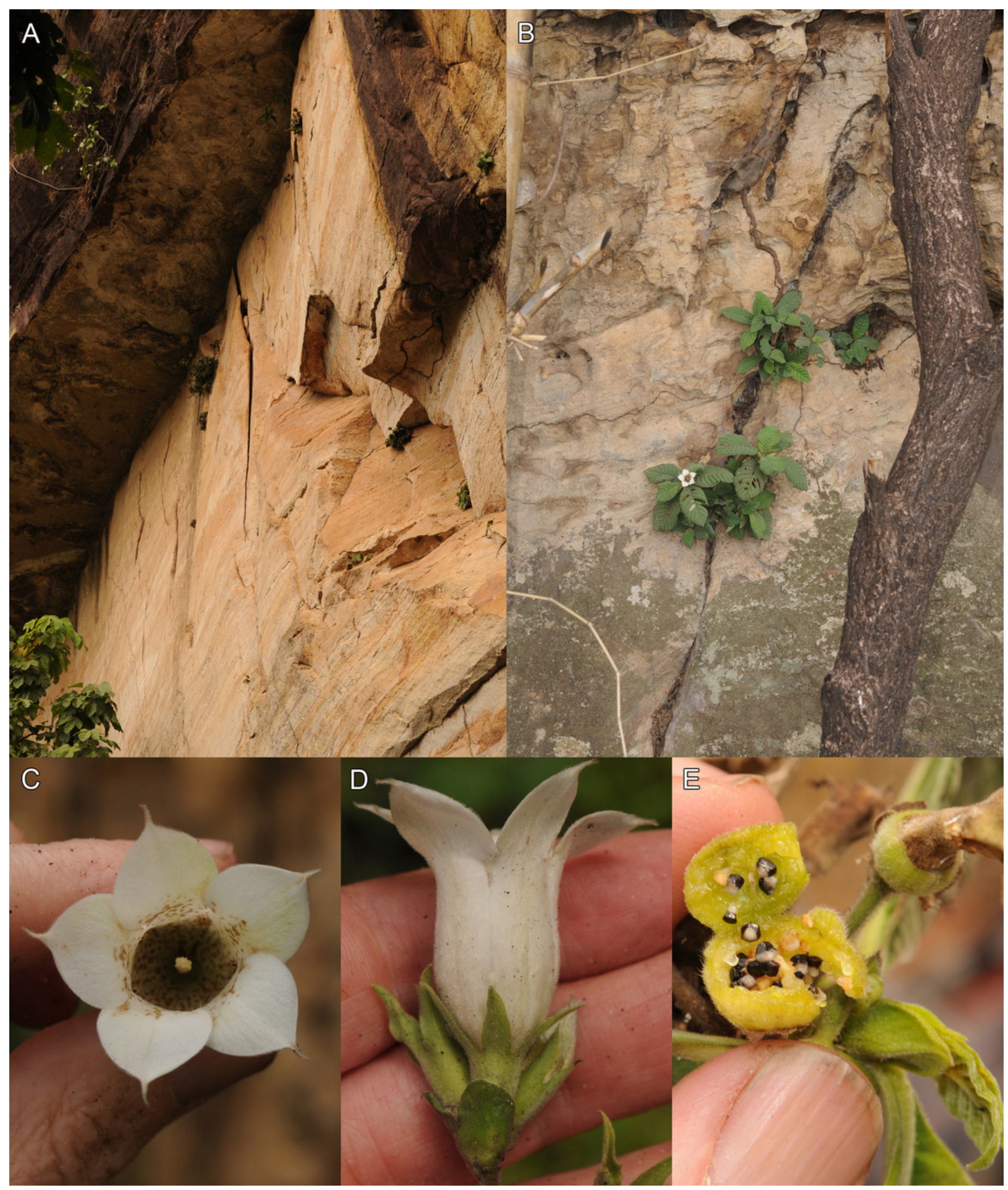




\section{Figure 2}

Scanning electron micrographs of triangular pollen (unacetolysed) of Kindia gangan.
(A) polar view;
(B) surface sculpturing. From Cheek 18541A.

*Note: Auto Gamma Correction was used for the image. This only affects the reviewing manuscript. See original source image if needed for review.

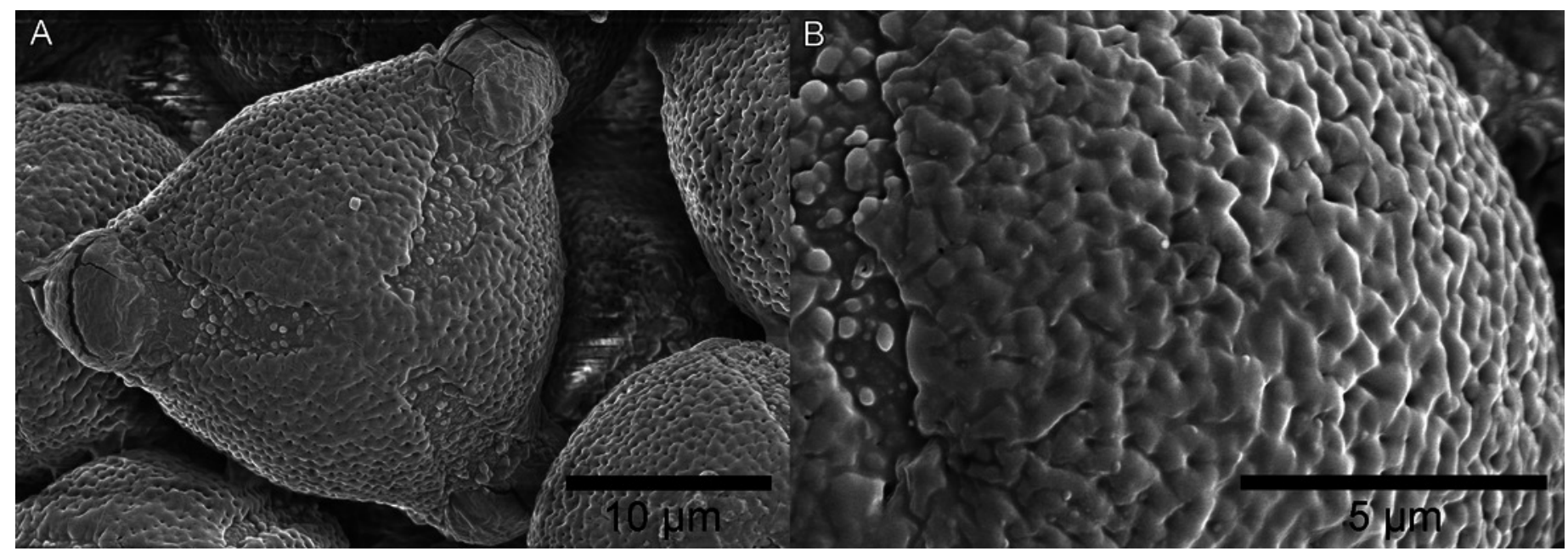


Figure 3

Summary phylogenetic hypothesis based on the concatenated BI analysis.

Clades I-IV were numbered according to De Block et al. (2015). 


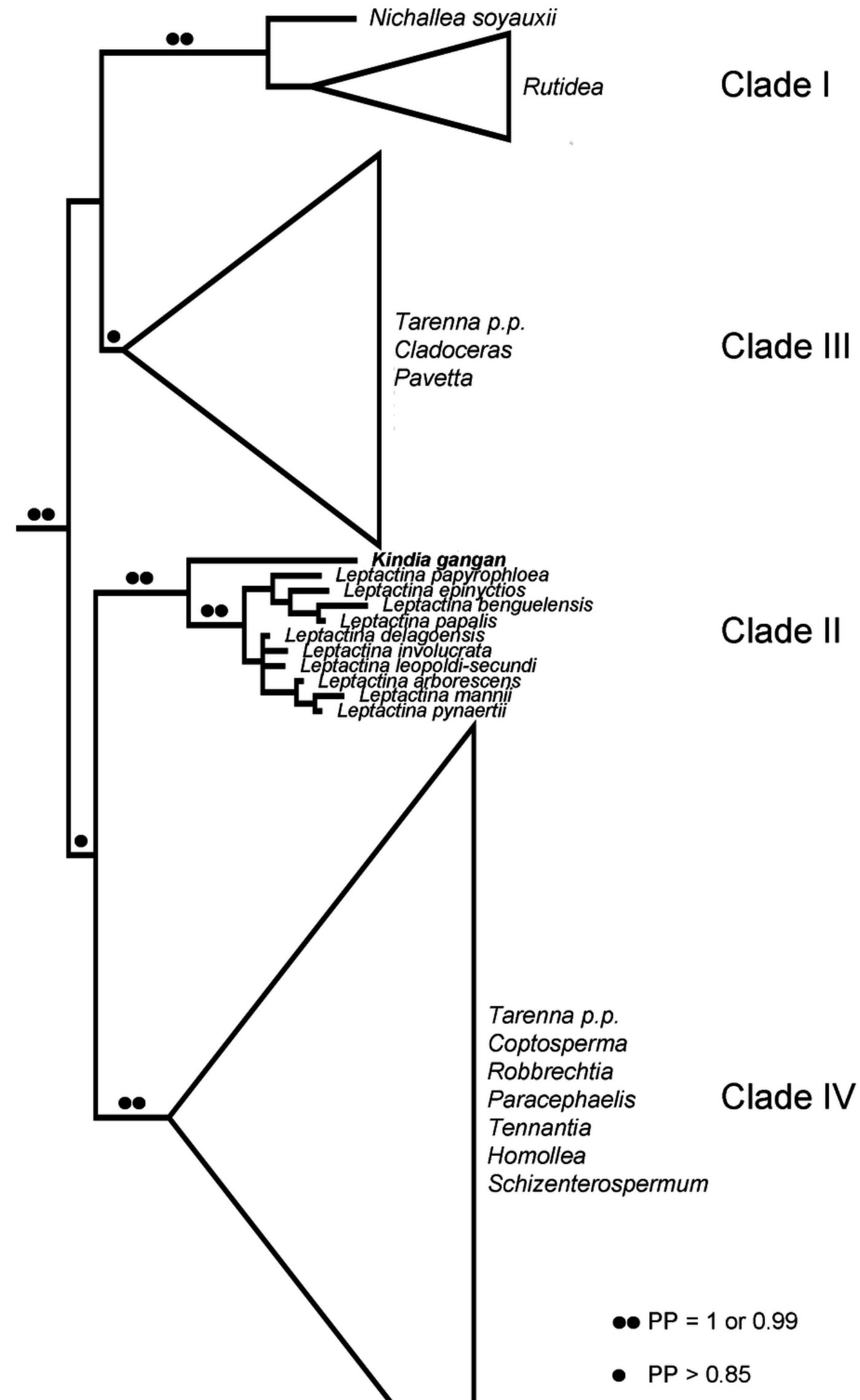




\section{Figure 4}

Kindia gangan Cheek.

(A) habit, with indication of bullate leaf surface; (b) plants in situ on rock face (from

photograph); (c) adaxial leaf indumentum around midrib; (d) abaxial leaf indumentum around midrib; (e) inner face of stipule at second node; (f) secretory colleter from e; (g) flower, postanthetic; (h) peduncle and proximal cup of bracts with lobes (sheathing and concealing a smaller distal cup of bracts) below flower; (i) corolla from post-anthetic flower cut longitudinally and opened to display inner surface; (J) stigma; (k) transverse section of mature fruit, empty of seeds but showing placenta (in the left locule); (I) seed, hydrated, lateral view; $(m)$ seed, dry, lateral view; $(n)$ seed, dry, view from above. Scale bars: $A, B=5$ $\mathrm{cm} ; \mathrm{G}, \mathrm{I}, \mathrm{K}=1 \mathrm{~cm} ; \mathrm{h}=5 \mathrm{~mm} ; \mathrm{c}, \mathrm{d}, \mathrm{e}, \mathrm{j}=2 \mathrm{~mm} ; \mathrm{f}, \mathrm{l}, \mathrm{m}, \mathrm{n}=1 \mathrm{~mm}$. Drawn by Andrew Brown based on Cheek 18345. 


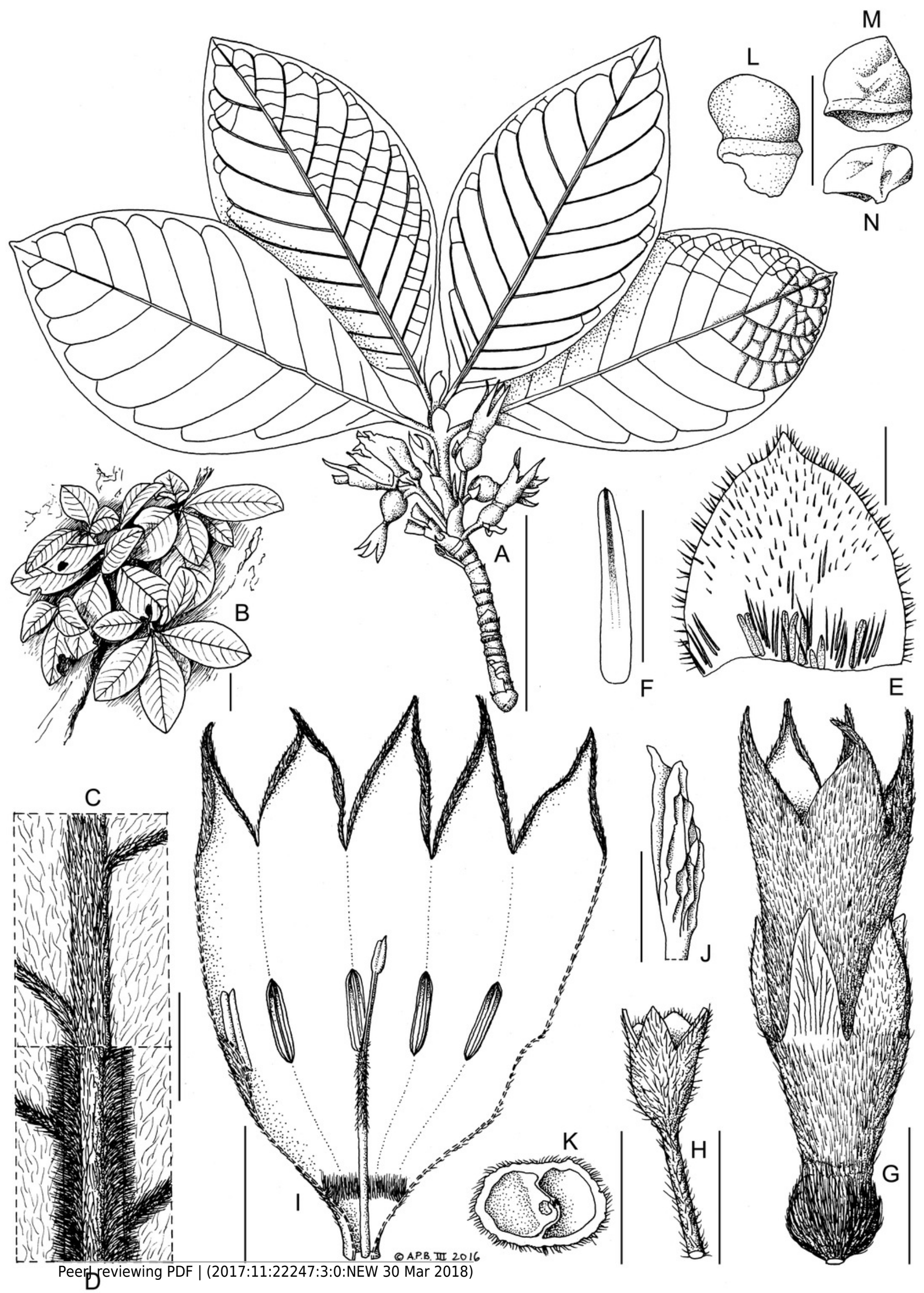


Figure 5

Map of the distribution of Kindia gangan.

The distribution of the species was mapped using SimpleMappr.

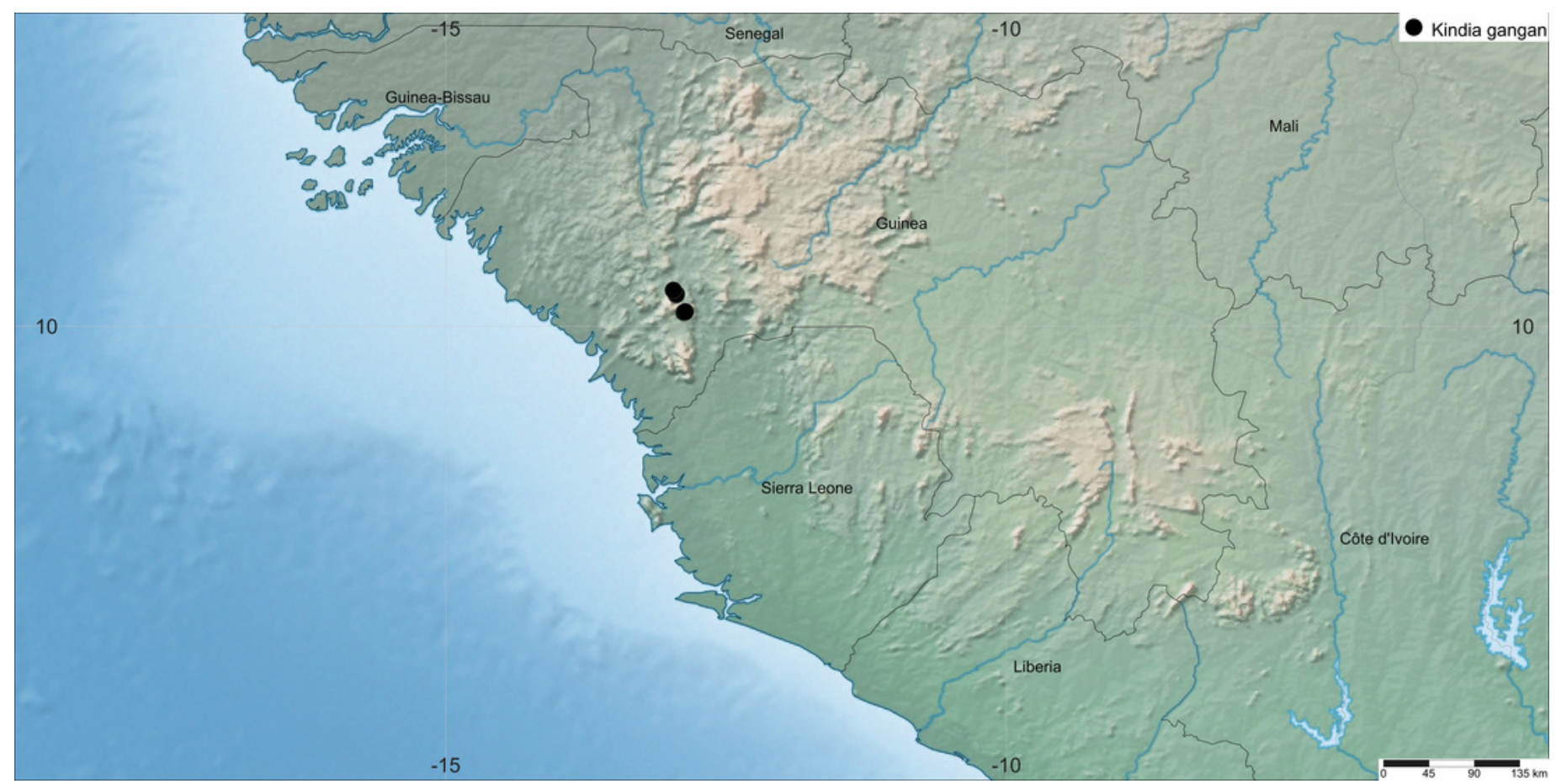

